\title{
NBP, a protein that specifically binds an enhancer of immunoglobulin gene rearrangement: purification and characterization
}

\author{
Min Li, Ewa Morzycka-Wroblewska' ${ }^{1}$, and Stephen V. Desiderio \\ Department of Molecular Biology and Genetics and Howard Hughes Medical Institute Laboratory of Genetics, \\ The Johns Hopkins University School of Medicine, Baltimore, Maryland 21205 USA
}

\begin{abstract}
Immunoglobulin and T-cell receptor (TCR) genes are encoded in discrete germ line DNA segments that are joined by site-specific recombination during lymphocyte development. These DNA rearrangements are mediated by conserved heptamer and nonamer DNA sequence elements that lie near the sites of recombination. In this paper we show that the nonamer element coincides with the recognition site for a specific DNA-binding protein: mutations within the nonamer sequence, but not outside of it, decrease affinity for the binding protein by 300- to 1000-fold. Deletion of the binding site for the protein results in at least a 50 -fold decrease in recombination frequency in vivo. By a combination of conventional and recognition site affinity chromatography, we have achieved $>20,000$-fold purification of the protein from calf thymus, with an overall yield of $22 \%$. The purified protein, which we now call nonamer-binding protein (NBP), has an apparent molecular weight of 63,000 and a frictional ratio of 1.27 , suggesting that it exists as a globular monomer in 0.5 $\mathrm{M} \mathrm{NaCl}$. Our observations suggest that NBP is a component of the recombinational apparatus.
\end{abstract}

[Key Words: Immunoglobulin gene rearrangement; lymphocyte development; DNA-binding proteins; specific DNA affinity chromatography]

Received July 10, 1989; revised version accepted August 24, 1989.

The variable regions of immunoglobulin chains are encoded by discrete germ line DNA segments that are brought together by site-specific recombination during lymphoid differentiation (for reviews, see Tonegawa 1983; Alt et al. 1987). For example, the variable regions of immunoglobulin heavy chains are encoded by three germ line elements; $\mathrm{V}_{\mathrm{H}}, \mathrm{D}$, and $\mathrm{J}_{\mathrm{H}}$ (Early et al. 1980; Sakano et al. 1980); during B-cell differentiation, individual segments from each group are joined to form a complete $\mathrm{V}_{\mathrm{H}}-\mathrm{D}-\mathrm{I}_{\mathrm{H}}$ unit. The genes that encode T-cell antigen receptors (TCR) show similar patterns of segmentation and rearrangement (Davis 1985). As a consequence of these rearrangements, a diverse set of variable regions is generated from a relatively small number of gene segments. Thus, immunoglobulin and TCR gene rearrangement play a central role in establishing the primary immune repertoire.

Unrearranged immunoglobulin and TCR gene segments are accompanied by heptamer and nonamer sequence elements, separated by a spacer region (Early et al. 1980; Sakano et al. 1980). Several lines of evidence indicate that these sequences mediate rearrangement.

'Present address: Department of Medicine, School of Medicine, University of California San Diego, La Jolla, California USA.
First, the heptamer and nonamer sequences are conserved among immunoglobulin and TCR gene families and among vertebrate species (Litman et al. 1985). Second, the heptamer-spacer-nonamer motif is located at the sites of recombination. Joining of coding sequences is accompanied by the formation of a reciprocal product in which the heptamer sequences of the participating gene segments are precisely joined (Lewis et al. 1985; Okazaki et al. 1987; Desiderio and Wolff 1988). Third, the spacer regions fall into two length classes of 12 and $23 \mathrm{bp}$; recombination normally occurs only between gene segments carrying spacers of different length (Early et al. 1980). Fourth, the heptamer-spacer-nonamer motif is sufficient to support rearrangement of exogenous recombinational substrates in cultured cells (Akira et al. 1987; Hess et al. 1987). Immunoglobulin and TCR gene segments are apparently recombined by a similar mechanism, as suggested by the correct joining of exogenous TCR gene segments in cultured B-progenitor cells (Yancopoulos et al. 1986). On the basis of these observations, it is likely that the conserved heptamer and nonamer elements represent binding sites for proteins involved in rearrangement of immunoglobulin and TCR genes.

We recently identified a protein that binds to DNA 
fragments containing immunoglobulin recombinational signal sequences from diverse sources (Halligan and Desiderio 1987). The specific binding activity was detected in extracts of nuclei from lymphoid cells but not in extracts from nonlymphoid cells. Because the protein was observed to bind to a DNA fragment containing a murine $\mathrm{J}_{\mathrm{K}} 4$ nonamer sequence, but not to a fragment containing the heptamer sequence, we inferred that the protein recognizes the nonamer.

In this paper we define the protein's DNA recognition site and examine the function of this site in vivo. In addition, we report the purification of this protein. The sequence required for DNA-protein binding was found to coincide precisely with the conserved nonamer recombinational signal: Mutations within the nonamer, but not outside of it, resulted in large decreases in affinity. Deletion of the nonamer sequence was observed to profoundly impair rearrangement of an immunoglobulin gene segment in vivo. The protein was purified by a combination of conventional methods and DNA recognition site affinity chromatography. We obtained a purification of $>20,000$-fold, with an overall yield of $22 \%$. The protein, which we now call nonamer-binding protein (NBP), has an apparent molecular weight of 63,000 , as judged by SDS-polyacrylamide gel electrophoresis; it behaves as a globular monomer in $0.5 \mathrm{M} \mathrm{NaCl}$. The specific binding of NBP to an enhancer of immunoglobulin gene rearrangement and its expression in nuclei of lymphoid cells suggest a role for NBP in the assembly of immunoglobulin and TCR genes.

\section{Results \\ Construction of mutant substrates for binding}

Previous experiments identified a protein in extracts of calf thymus nuclei that specifically binds DNA fragments containing recombinational signal sequences from a variety of immunoglobulin gene segments. Within a fragment from the immunoglobulin $\mathrm{J}_{\mathrm{K}} 4$ gene segment, the binding site was localized to a $27-\mathrm{bp}$ interval spanning the nonamer region (Halligan and Desiderio 1987). To define the binding site, we constructed a series of mutant DNA fragments and assayed their ability to compete with a wild-type $J_{K} 4$ DNA fragment for binding.

Comparison of the nucleotide sequences of $137 \mathrm{im}$ munoglobulin and TCR gene segments revealed that the nonamer motif (consensus GGTTTTTGT), is well conserved but exhibits some variability nonetheless (Fig. 1). Because of this fact and our observation that the protein binds DNA fragments containing differing nonamer sequences (Halligan and Desiderio 1987, and B. Halligan and S.V. Desiderio, unpubl.), we elected to construct mutant substrates with multiple nucleotide substitutions. Nine different pairs of complementary, 24-mer oligonucleotides were synthesized, annealed, and ligated into pUC13 to yield a series of plasmids, each containing an 18-bp sequence spanning the $J_{K} 4$ nonamer (Fig. 2). In one of the plasmids (pNM13/14), the 18-bp core sequence was identical to the wild-type $\mathrm{J}_{\mathrm{K}} 4$ sequence. Of the remaining plasmids, six (pNM1/2, pNM3/4, pNM5/6, pNM 7/8, pNM $9 / 10$, and pNM11/12) contained a 3-bp substitution, whereas two (pNM60/61 and pNM62/63) contained a 2-bp substitution (Fig. 2). Cleavage of each plasmid with $H$ indIII and EcoRI yielded a 54-bp DNA fragment containing the mutant or wildtype sequence; these fragments served as competitors in protein-binding assays.

\section{Definition of the binding site for the protein}

The formation of specific DNA-protein complexes was detected by an electrophoretic mobility shift assay. The source of the protein used in the assay was the active fraction from Bio-Rex-70, the first column used in purifi-
Figure 1. Nucleotide usage near immunoglobulin and TCR nonamer signal sequences. The sequences of 137 immunoglobulin and TCR gene segments within a 21-bp interval spanning the nonamer were aligned by inspection. The nucleotide frequency at each position on the upper strand was computed. Sequences are oriented so that the spacer region lies toward the right; The nonamer region extends from position 7 to 15 ; positions 16-21 lie in the spacer region. Open bars represent percent $C_{\text {; }}$ shaded bars, percent $T$; hatched bars, percent $A_{\text {; }}$ solid bars, percent $G$. The sequences used in the computation were obtained from the compilation of Kabat et al. (1987), and from the following additional references: Bernard et al. (1978); Tonegawa et al. (1978); Max et al. (1979); Sakano et al. (1979); Early et al. (1980), Max et al. (1980); Bothwell et al. (1981); Cohen and Givol (1983); Chen et al. (1984); Heinrich et al. (1984); Yancopoulos et al. (1984); Hayday et al. (1985); Litman et al. (1985); Concannon et al. (1986); LeFranc et al. (1986); Ichihara et al. (1988).

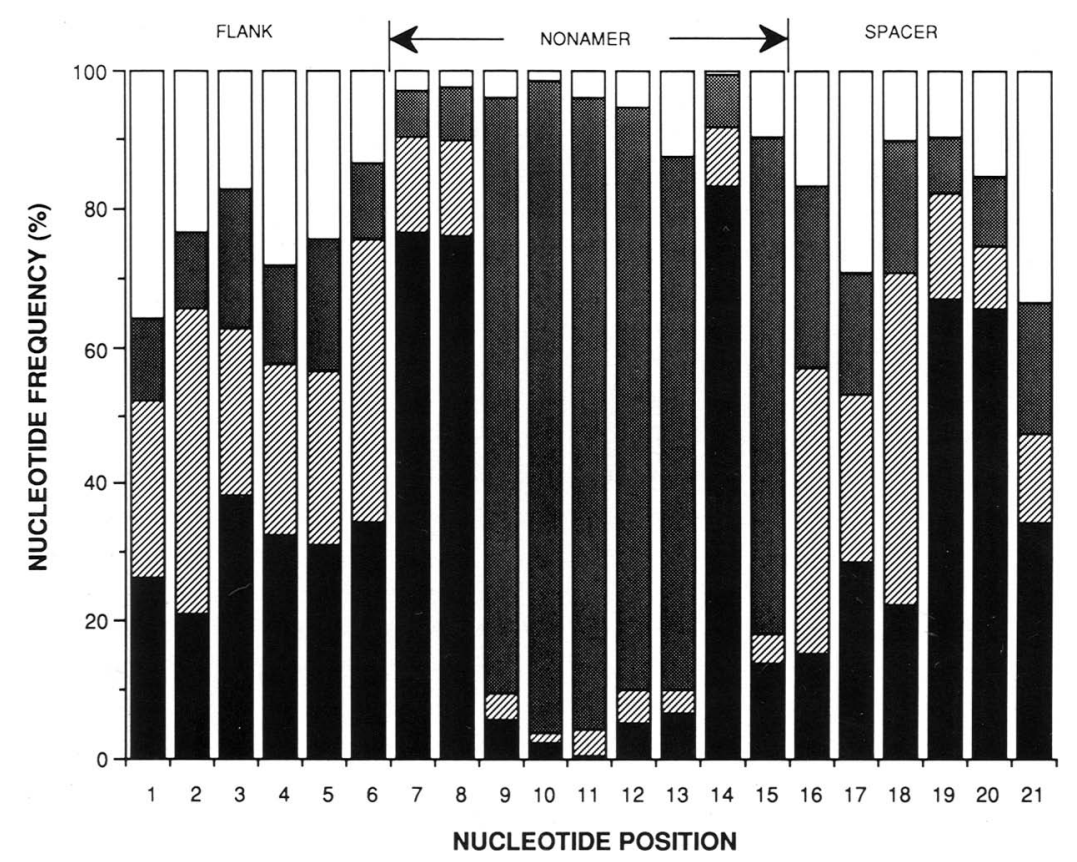




\begin{abstract}
$J_{\kappa}^{4}$ ... GCAGGTTTTTGTAAAGGG. . .

PNM13/14 GGATCCGCAGGTTTTTGTAAAGGGGAATTC PNM 1/2 GGATCCTACGGTTTTTGTAAAGGGGAATTC PNM 3/4 GGATCCGCATTGTTTTGTAAAGGGGAATTC pNM 5/6 GGATCCGCAGGTGGGTGTAAAGGGGAATTC pNM 7/8 GGATCCGCAGGTTTTCACAAAGGGGAATTC pNM 9/10 GGATCCGCAGGTTTTTGTCCCGGGGAATTC pNM 11/12 GGATCCGCAGGTTTTTGTAAATTTGAATTC pNM 60/61 GGATCCGCATTTTTTTGTAAAGGGGAATTC

\section{pNM 62/63 GGATCCGCAGGTTTTTACAAAGGGGAATTC}

Figure 2. Sequences of wild-type and mutant DNA fragments used in competition experiments. Complementary, 24-baselong oligonucleotide pairs (NM1/NM2, NM3/NM4, NM5/ NM6, NM7/NM8, NM9/NM10, NM11/NM12, NM13/NM14, NM60/NM61, and NM62/NM63) were synthesized and annealed; the resulting duplex DNA, flanked by EcoRI and $B a m H I$ restriction sites, was ligated into the plasmid pUC13. The resulting plasmids were designated $\mathrm{pNM} 1 / 2$, $\mathrm{pNM} 3 / 4$, $\mathrm{pNM} 5 / 6, \mathrm{pNM} 7 / 8, \mathrm{pNM} 9 / 10, \mathrm{pNM} 11 / 12, \mathrm{pNM} 13 / 14, \mathrm{pNM} 60 /$ 61 , and pNM62/63. (Top line) Sequence of the murine $I_{\mathrm{K}} 4$ segment in an 18-bp interval spanning the nonamer. The nonamer sequence is underlined. (Remaining lines) Sequences of synthetic DNA fragments from the BamHI site to the EcoRI site. Only the upper strand is shown. Mutations within the 18-bp interval corresponding to the $\mathrm{J}_{\mathrm{K}} 4$ sequence are shown in boldface type.

cation of the protein (see below); the labeled DNA fragment was the 27-bp DdeI-HinPI fragment of pJ 4 4.copy96 (Halligan and Desiderio 1987), which spans the $\mathrm{J}_{\mathrm{K}} 4$ nonamer sequence. Figure $3 \mathrm{~A}$ shows the results of an assay in which the 54-bp HindIII-EcoRI fragment from $\mathrm{pNM} 13 / 14$ was used as a specific competitor. In the absence of the pNM13/14 fragment, we observed a species of altered mobility that was not detected in the absence of added protein (Fig. 3A, lanes b and a). In the presence of increasing amounts of the specific competitor, the yield of this species decreased approximately linearly, demonstrating that binding is directed to the 18-bp sequence shared by the pNM13/14 fragment and the $\mathrm{J}_{\mathrm{K}} 4$ fragment and that the affinity of the protein for each of these fragments is similar (Fig. 3A, lanes c-k).

When the mutant fragments were used as specific competitors in the binding assay, we found that fragments from pNM1/2, pNM $9 / 10$, and $\mathrm{pNM} 11 / 12$ competed with the $\mathrm{J}_{\mathrm{K}} 4$ fragment for binding, whereas fragments from pNM3/4, pNM5/6, and pNM $7 / 8$ competed very poorly or not at all (Fig. 3B). The amount of bound, labeled DNA recovered from each reaction was quantitated by densitometry and normalized to the amount of bound, labeled DNA recovered in the absence of competitor; this value $\left(B / B_{0}\right)$ is expressed in Figure $4 \mathrm{~A}$ as a function of the mass of added competitor. Assuming that the protein binds DNA with a stoichiometric ratio of 1 , we estimate that the fragments from $\mathrm{pNM} 3 / 4$, pNM5/6, and pNM7/8 have at least a 1000 -fold lower affinity for the binding protein than does the wild-type fragment from $\mathrm{pNM} 13 / 14$. In contrast, the fragments from $\mathrm{pNM} 1 / 2$, $\mathrm{pNM} 9 / 10$, and $\mathrm{pNM} 11 / 12$ bound the protein with an affinity similar to that of the wild-type fragment. To exclude the possibility that the $5 \mathrm{~T} / \mathrm{A}$ base pairs in the center of the nonamer are sufficient for binding, we measured the relative affinities of fragments from pNM60/61 and pNM62/63, in which the initial GG or terminal GT dinucleotide of the nonamer was mutated (Fig. 2). These mutations also resulted in large (300- and 1000-fold) decreases in affinity, indicating that these dinucleotides are crucial for binding (Fig. 4B). The mutants pNM3/4, pNM5/6, pNM7/8, pNM60/61, and pNM62/63 therefore define a site, from 7 to $9 \mathrm{bp}$ in length, that directs specific protein binding. This site coincides with the conserved nonamer recombinational sequence (Figs. 2, and 4A,B). We shall henceforth refer to the protein as NBP.

\section{Deletion of the binding site for NBP impairs recombination in vivo}

If the nonamer element plays a role in recombination, deletion of the nonamer would be expected to impair rearrangement. To test this, we assayed the rearrangement of wild-type and mutant $V_{H}$ segments that were stably integrated into the genome of a B-lymphoid progenitor cell line by retroviral transduction (Desiderio and Wolff 1988; Morzycka-Wroblewska et al. 1988). The wild-type substrate for recombination, pLJHCR-2 (Fig. 5), has been described (Morzycka-Wroblewska et al. 1988) and contains three murine immunoglobulin gene segments: $\mathrm{V}_{\mathrm{H}}$, $\mathrm{DI}_{\mathrm{H}}$ and $\mathrm{J}_{\mathrm{H}}$. Between the $\mathrm{V}_{\mathrm{H}}$ and $\mathrm{DI}_{\mathrm{H}}$ segments lies the gpt gene of Escherichia coli. The immunoglobulin gene segments are arranged so that joining of $\mathrm{V}_{\mathrm{H}}$ to $\mathrm{DJ}_{\mathrm{H}}$ or to $\mathrm{J}_{\mathbf{H}}$ results in an inversion of the intervening DNA. The mutant substrate $\mathrm{pLJHCR}-2 \Delta \mathrm{N}$, which was derived from pLJHCR-2, carries a deletion that removes the nonamer element and $2 \mathrm{bp}$ of spacer DNA from the recombinational signal sequence of $\mathrm{V}_{\mathrm{H}}$ (Fig. 5).

The pLJHCR-2 and pLJHCR- $2 \Delta \mathrm{N}$ constructs were packaged and transmitted to the B-progenitor cell line HAFTL-1 (Alessandrini et al. 1987). Derivatives of HAFTL-1 that contained integrated provirus were selected in G418. Rearrangement of the substrates in individual clones of HAFTL- 1 cells was assayed by digestion of genomic DNA with KpnI and hybridization to probes specific for gpt or neo sequences (Morzycka-Wroblewska et al. 1988). Digestion of unrearranged proviral DNA creates a $2.4-\mathrm{kb}$ fragment that hybridizes to a gpt-specific probe and a $4.0-\mathrm{kb}$ fragment that hybridizes to a neo-specific probe. Proviral DNA that has undergone $\mathrm{V}_{\mathrm{H}^{-}}$-to-DJ $\mathrm{H}_{\mathrm{H}}$ joining yields a $4.8 \mathrm{-kb}$ fragment that hybridizes to both probes. Of 183 HAFTL-1 clones containing the wild-type substrate, 80 yielded a $4.8 \mathrm{~kb}$ neocontaining KpnI fragment that also hybridized to the gpt probe, consistent with $\mathrm{V}_{\mathrm{H}^{-}}$-to- $\mathrm{DJ} \mathrm{J}_{\mathrm{H}}$ joining within the substrate (Fig. 5). Of 139 clones containing the mutant sub- 
Li et al.
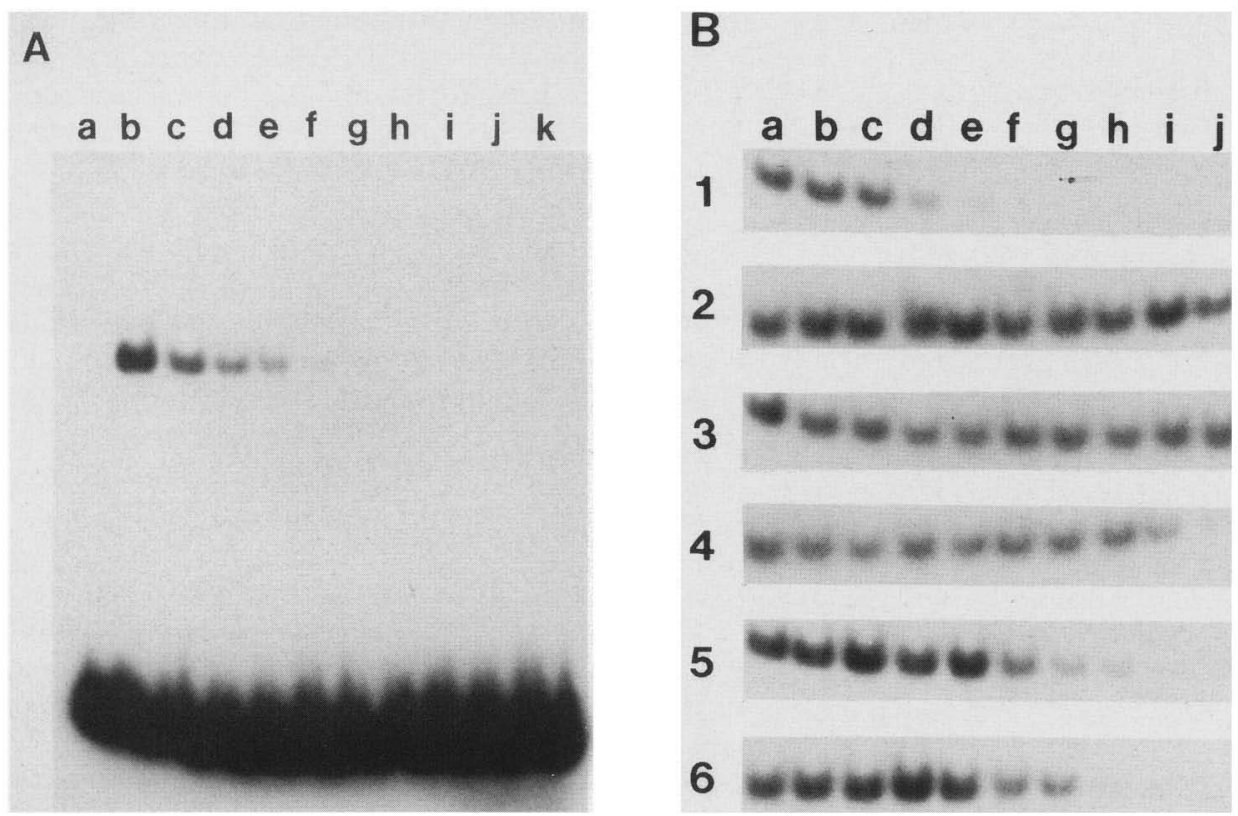

Figure 3. Assays for competition by wild-type and mutant DNA fragments $|A|$ Assay for competition by a DNA fragment containing the consensus nonamer sequence. Labeled, 27 -bp DdeI-HinPI fragment $(0.01 \mathrm{ng})$ from $\mathrm{pJ}_{\mathrm{K}} 4$.copy96 was assayed for formation of a specific DNA-protein complex in the presence of $2 \mu \mathrm{l}(2 \mu \mathrm{g})$ of partially purified protein (Bio-Rex-70 pool), as described in Methods. Reactions contained variable amounts of the 54-bp HindIII-EcoRI fragment from pNM13/14 (specific competitor), which was quantitated by fluorimetry. (Lane $a$ ) No extract, no specific competitor; (lane $b$ ) no specific competitor; (lanes $c-k$ ) reactions containing the pNM13/14 fragment in twofold increments from 10.2 to $2600 \mathrm{pg}$. (B) Assays for competition by mutant fragments. Assays were performed as described in $A$ and Methods. (Lane $a$ ) contains no specific competitor, whereas lanes $b-j$ contain twofold increments of a 54-bp, specific competitor fragment. The sources of competitor fragments and the amounts added are pNM1/2, 7.8-2000 pg (1); pNM3/4, 78-20,000 pg (2); pNM5/6, 74-19,000 pg (3); pNM7/8, 90-23,000 pg (4); pNM9/10, 4.7-1,200 pg (5); pNM11/12, 6.3-1600 pg (6).

A

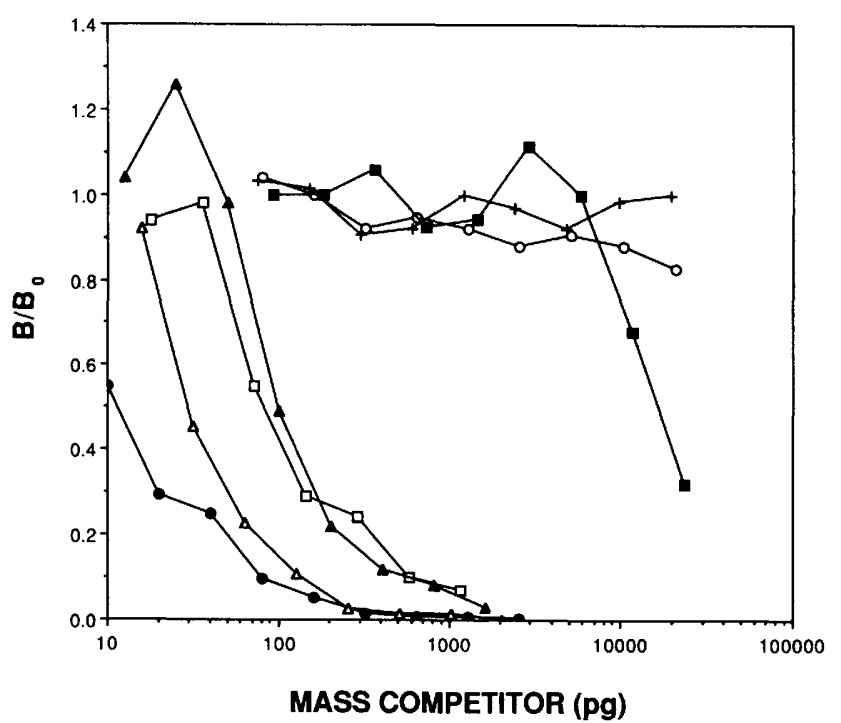

B

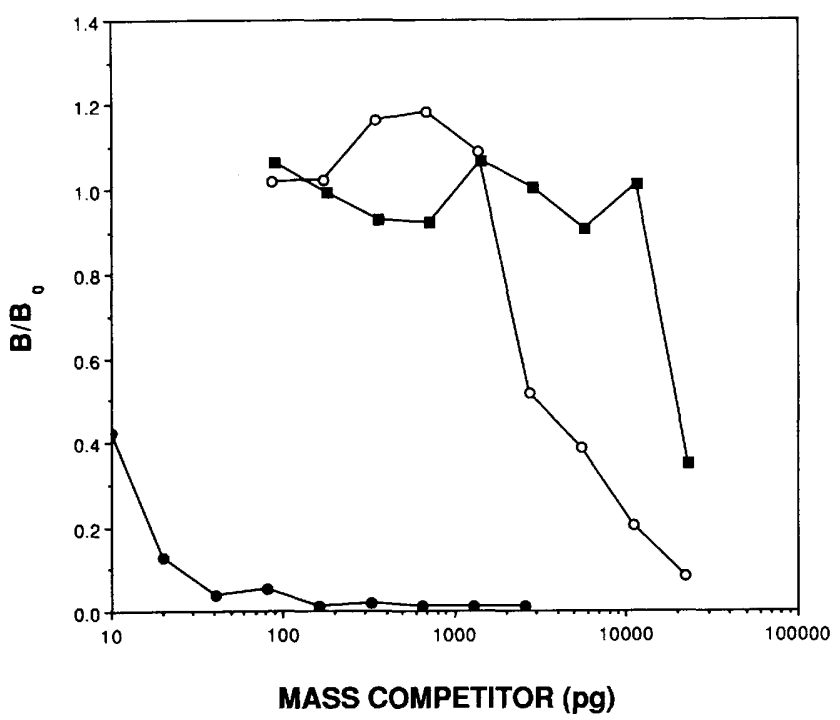

Figure 4. Effects of mutation on the relative affinity of DNA-protein binding. $\{A \mid$ DNA fragments containing trinucleotide substitutions. The amount of labeled DNA bound in the presence of competitor was quantitated by densitometry and normalized to the amount bound in the absence of competitor. This value $\left(\mathrm{B} / \mathrm{B}_{0}\right)$ is displayed as a function of the mass of competitor added. $(\triangle)$ Compet-

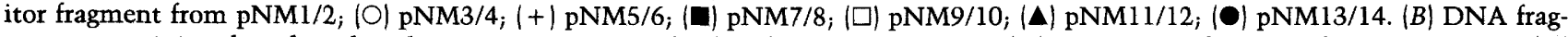
ments containing dinucleotide substitutions. Data are displayed as described in $A$. (O) Competitor fragment from pNM60/61; ( pNM62/63; (O) pNM13/14. 


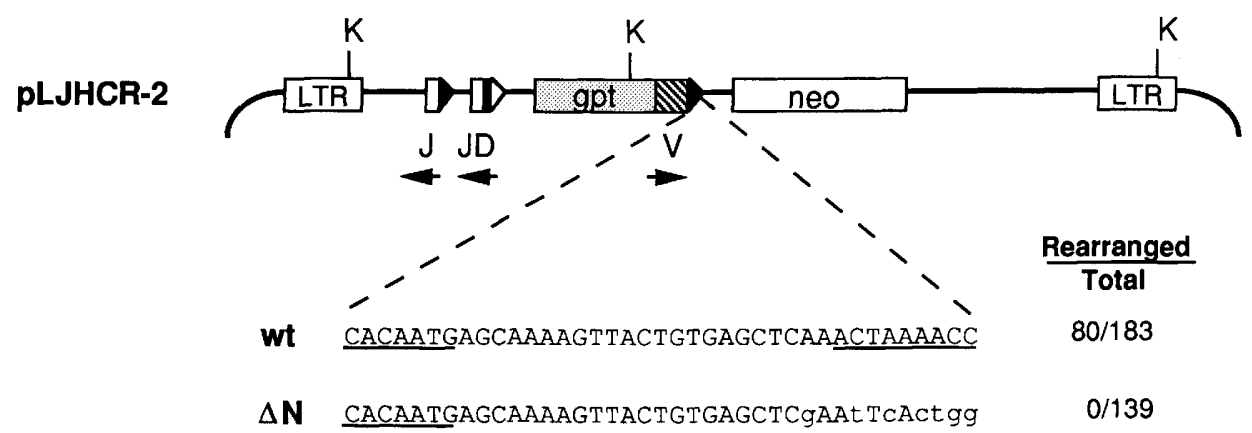

Figure 5. Effect of nonamer deletion on rearrangement in vivo. (Top line) The retroviral substrate for recombination, pLJHCR-2. The Moloney murine leukemia virus long terminal repeats (LTRs), the gpt gene, and the neo gene are indicated. The D sequence is indicated by a solid box, the $\mathrm{J}_{\mathrm{H}}$ sequences, by open boxes, and the $\mathrm{V}_{\mathrm{H}}$ sequence, by a hatched box. The transcriptional orientations of the immunoglobulin gene segments are indicated by arrows. Recombinational signal sequences carrying 23- and 12-bp spacers are indicated by solid and open triangles, respectively. Sequences surrounding the retroviral LTR are not included. $(K) K p n I$ restriction sites. (Center and bottom lines) Sequences of pLJHCR-2 and pLJHCR-2 $\Delta \mathrm{N}$ in the 39-bp interval $3^{\prime}$ to the $\mathrm{V}_{\mathrm{H}}$ coding region. Residues in the mutant sequence that differ from wild-type are written in lowercase letters. The number of cell clones containing rearranged provirus and the number of cell clones assayed are shown (right).

strate, none showed evidence of $\mathrm{V}_{\mathrm{H}^{-}}$to- $\mathrm{DJ} \mathrm{J}_{\mathrm{H}}$ or $\mathrm{V}_{\mathrm{H}^{-}}$-to- $\mathrm{J}_{\mathrm{H}}$ joining by this assay (Fig. 5). Thus, removal of $11 \mathrm{bp}$ from the recombinational signal sequence of the $V_{H}$ gene segment, including the nonamer and $2 \mathrm{bp}$ of the adjacent spacer sequence, results in at least a 50 -fold decrease in the frequency of rearrangement.

The deletion in the substrate pLJHCR-2 $\Delta \mathrm{N}$ was found to abolish specific binding of NBP to the $3^{\prime}$ flank of the $\mathrm{V}_{\mathrm{H}}$ gene segment; conversely, a DNA fragment containing the deleted sequence was able to bind NBP specifically (data not shown). We conclude that the deletion in $\mathrm{pLJHCR}-2 \Delta \mathrm{N}$ spans a recognition site for NBP.

\section{Recovery of active NBP from SDS-polyacrylamide gels}

To determine the approximate size of the polypeptide(s) that binds to the nonamer sequence, protein from the Bio-Rex-70 pool (see below) was denatured in SDS and 2-mercaptoethanol and fractionated by electrophoresis through an SDS-polyacrylamide gel. The lane containing the protein was cut into $10-\mathrm{mm}$ slices. Protein was eluted from each slice, renatured in guanidine hydrochloride, and assayed for DNA binding activity by the electrophoretic mobility shift assay (Fig 6A). Activity was recovered from a single gel slice, which contained protein ranging in molecular weight from 55,000 to 65,000 (Fig. 6A, lane f). The mobility of the DNAprotein complex formed in the presence of renatured protein was identical to the mobility of the complex formed with native protein (Fig. 6A, lanes $b$ and f). To determine whether the renatured activity had the same specificity as the native protein, reactions were performed in the presence of $1.5 \mathrm{ng}$ of specific competitor DNA (Fig. 6B). The wild-type DNA fragment from pNM13/14 (Fig. 6B, lane c) and mutant fragments from pNM1/2 (Fig. 6B, lane d), pNM9/10 (Fig. 6B, lane h), and pNM11/12 (Fig. 6B, lane i) competed with the $J_{K} 4$ fragment for binding to the renatured protein, whereas mutant fragments from pNM3/4, pNM5/6, and pNM $7 / 8 \mathrm{did}$ not (Fig. 6B, lanes e, $-\mathrm{g}$ ). Thus, the renatured binding ac- tivity, like the native protein, recognizes a site that coincides with the conserved nonamer sequence.

\section{Purification of NBP}

As a prerequisite to understanding the function of NBP, we purified the protein on the basis of its specific DNA binding activity. The purification is summarized in Table 1. Calf thymus proved to be an excellent source of activity. An extract of calf thymus nuclei was prepared, and specific binding activity was quantitatively precipitated in $\left(\mathrm{NH}_{4}\right)_{2} \mathrm{SO}_{4}$. The precipitate was chromatographed on the cationic exchange resin Bio-Rex-70 (Fig. $7 \mathrm{~A}_{;}$Table 1). The DNA binding activity eluting at 280 $\mathrm{mM} \mathrm{NaCl}$ was shown to be specific for the nonamer sequence by the competition assays presented above. Additional DNA binding activities eluted at higher $\mathrm{NaCl}$, but these were found to be nonspecific by the mobility shift assay (data not shown). The active pool from BioRex-70 was chromatographed on heparin agarose (Fig. $7 \mathrm{~B}$; Table 1). In this step, the nonamer binding activity was separated from the major protein peak. The active pool from heparin agarose was chromatographed on nonspecific DNA-Sepharose (Fig. 7C, Table 1); in this step, 28-fold purification was achieved with a yield of $70 \%$.

The nonamer binding activity pool from nonspecific DNA-Sepharose was still inhomogeneous. Recognition site affinity chromatography, developed by Rosenfeld and Kelly (1986) and Kadonaga and Tjian (1986), has proved useful in the purification of a number of specific DNA-binding proteins and seemed likely to be applicable here. We therefore constructed a specific nonamer affinity matrix. The active fraction from nonspecific DNA-Sepharose was chromatographed on the nonamer affinity column in the presence of nonspecific competitor DNA poly[d(I-C)]; Fig. 8A; Table 1). The column was washed with binding buffer containing $205 \mathrm{~mm} \mathrm{NaCl}$. The column was then developed with the same buffer containing $580 \mathrm{~mm} \mathrm{NaCl}$. Nonamer binding activity was 
Li et al.

Figure 6. Recovery of nonamer-binding activity after electrophoresis through SDS-polyacrylamide $(A)$ Protein $(600 \mu \mathrm{g})$ from the active BioRex-70 fraction was boiled in SDS and 2-mercaptoethanol and fractionated by electrophoresis through SDS-polyacrylamide. The lane containing the protein was cut into $10-\mathrm{mm}$ wide slices; protein was eluted and renatured in guanidinium chloride as described in Methods. Renatured protein was assayed for specific binding to the $27-b p J_{K} 4$ probe by the mobility shift assay. (Lane a) No protein; (lane b) $2 \mu l(2 \mu \mathrm{g})$ of the Bio-Rex-70 pool; (lanes $c-1) 5 \mu$ l of protein from each gel slice. The positions of molecular weight standards in relation to the gel slices assayed are indicated at bottom. $(B)$ Renatured binding activity retains specificity for the nonamer. The active gel fraction was assayed for binding to the $27-\mathrm{bp} \mathrm{J}_{\mathrm{K}} 4$ probe $(0.01 \mathrm{ng}$ per reaction) in the presence of specific competitor fragments. (Lane $a$ ) No protein or specific competitor added; (lane $b$ ) no specific competitor; (lanes $c-i$ ) assays per-

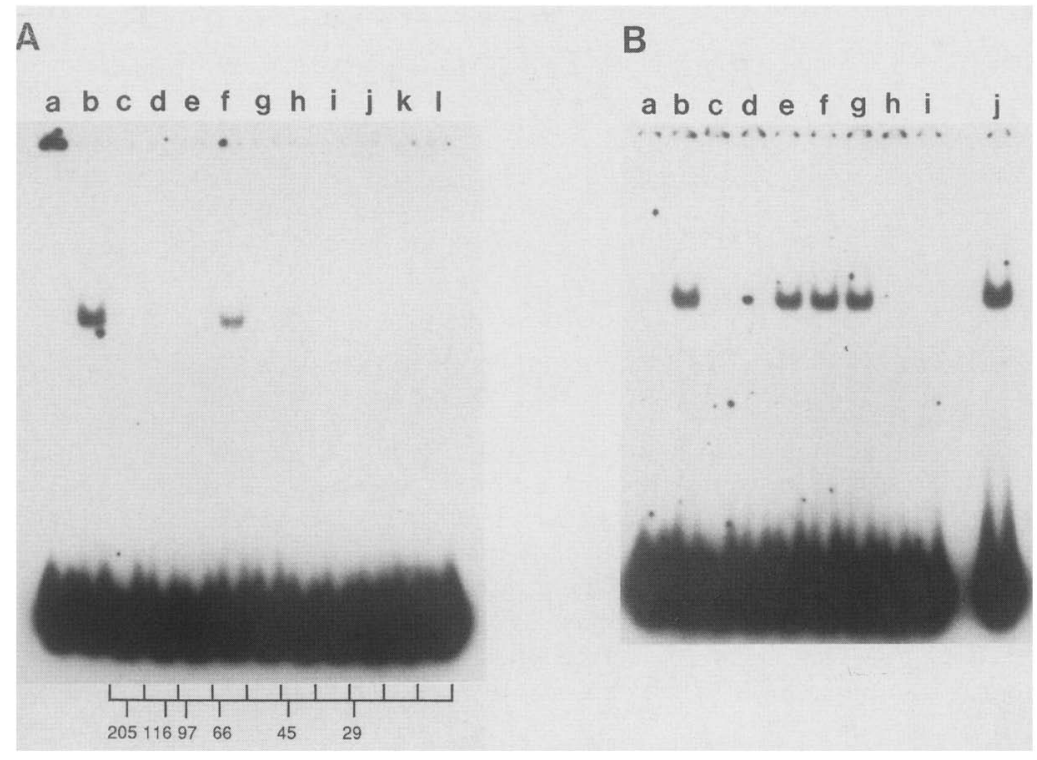
formed in the presence of $1500 \mathrm{pg}$ of the 54-bp HindIII-EcoRI fragment from pNM13/14, pNM1/2, pNM3/4, pNM5/6, pNM7/8, pNM9/10, or pNM11/12; (lane i) protein $(2 \mu \mathrm{g})$ from the Bio-Rex-70 pool, assayed in the absence of specific competitor.

nearly quantitatively $(92 \%)$ recovered in the $580 \mathrm{~mm}$ $\mathrm{NaCl}$ eluate. By the Bradford assay, which has a sensitivity of $\sim 1 \mu \mathrm{g}$ of protein per $\mathrm{ml}$ (Bradford 1976), no protein was detectable in the active pool from the nonamer affinity column. On this basis we estimate that at least a 10-fold purification was obtained in this step. Examination of the column fractions by SDS-polyacrylamide gel electrophoresis and silver staining indicates that the purification obtained by affinity chromatography was, in fact, far greater (Fig. 8B, see below).

\section{Physical characterization of NBP}

By SDS-polyacrylamide gel electrophoresis and silver staining, a predominant polypeptide of $63 \mathrm{kD}$ was detected in the $580 \mathrm{~mm} \mathrm{NaCl}$ eluate from the nonamer affinity column (Fig. 8B). The $63-\mathrm{kD}$ polypeptide comigrated with the nonamer binding activity (Fig. 8A,B), in agreement with our earlier assessment of the apparent molecular weight of NBP (Fig. 6A). Furthermore, when protein from the active Bio-Rex-70 pool was fractionated by SDS-polyacrylamide gel electrophoresis and transferred to nitrocellulose, a $63-\mathrm{kD}$ polypeptide was observed to bind specifically to a radiolabeled, 27-bp DNA probe containing the nonamer (data not shown). To prove that the $63-\mathrm{kD}$ polypeptide recovered from the affinity column represented NBP, protein from the activity peak was fractionated by SDS-polyacrylamide gel electrophoresis and the $63-\mathrm{kD}$ polypeptide was recovered from the gel. The eluted protein was renatured and shown to possess nonamer-binding activity (Fig. $8 \mathrm{C}$ ). We conclude that the $63-\mathrm{kD}$ polypeptide represents NBP.

In previous assays for nonamer-binding activity in protein eluted from SDS gels, we had inconsistently observed, in addition to the $63-\mathrm{kD}$ species, a nonamerbinding species of $\sim 45 \mathrm{kD}$ (data not shown). It is possible that the $45-\mathrm{kD}$ polypeptide is a proteolytic fragment of the $63-\mathrm{kD}$ protein, although alternative explanations, including heterogeneous post-translational modification and the existence of a distinct nonamer-binding species, have not been eliminated.

The subunit composition and shape of NBP in solu-

Table 1. Affinity purification of NBP

\begin{tabular}{lcccrr}
\hline Fraction & $\begin{array}{c}\text { Protein } \\
\text { (mg) }\end{array}$ & $\begin{array}{c}\text { Activity } \\
\text { (units) }\end{array}$ & $\begin{array}{c}\text { Specific } \\
\text { activity } \\
\text { (units/mg) }\end{array}$ & $\begin{array}{c}\text { Total } \\
\text { yield } \\
\text { (\%) }\end{array}$ & $\begin{array}{c}\text { Purification } \\
\text { (fold) }\end{array}$ \\
\hline I Nuclear extract & 1,030 & 45,000 & 43.7 & 100 & 100 \\
II $\left(\mathrm{NH}_{4}\right)_{2} \mathrm{SO}_{4}$ ppt & 747 & 45,000 & 60.2 & 42.4 & 1.4 \\
III Bio-Rex-70 & 72 & 19,070 & 2,990 & 33.8 & 6.1 \\
IV Heparin-agarose & 5.1 & 15,225 & 83,898 & 23.7 & 1,920 \\
V DNA-Sepharose & 0.13 & 10,655 & $>874,000$ & 21.9 & $>20,000$ \\
VI Nonamer affinity & $<0.011$ & 9,864 & & \\
\hline
\end{tabular}


A
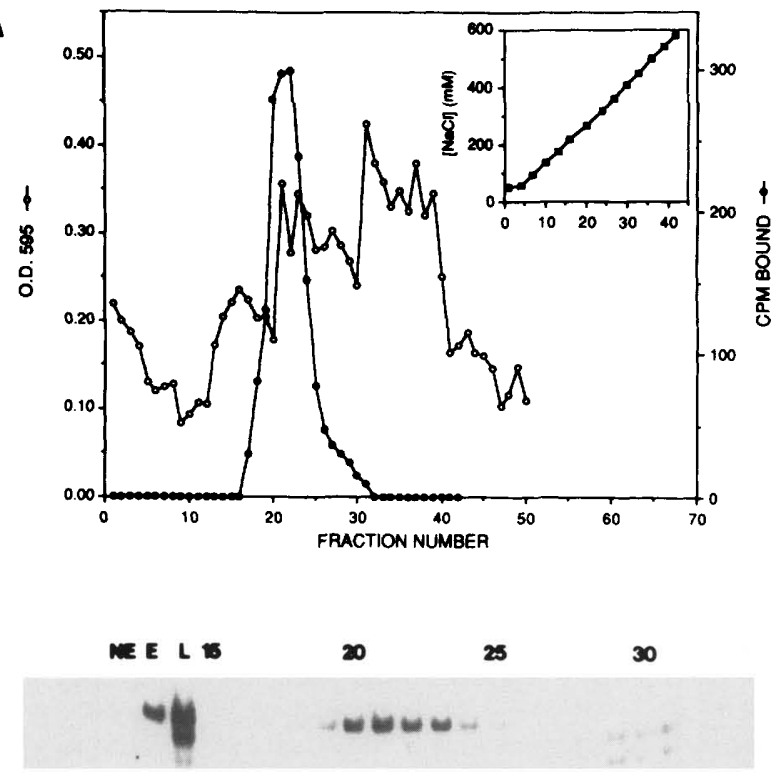

C
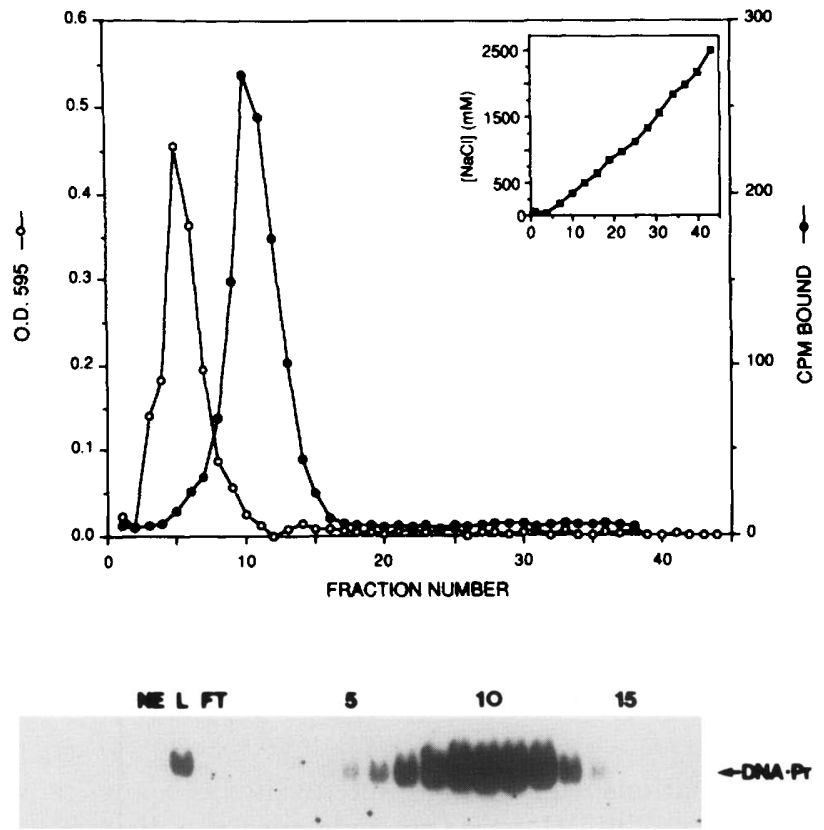

B
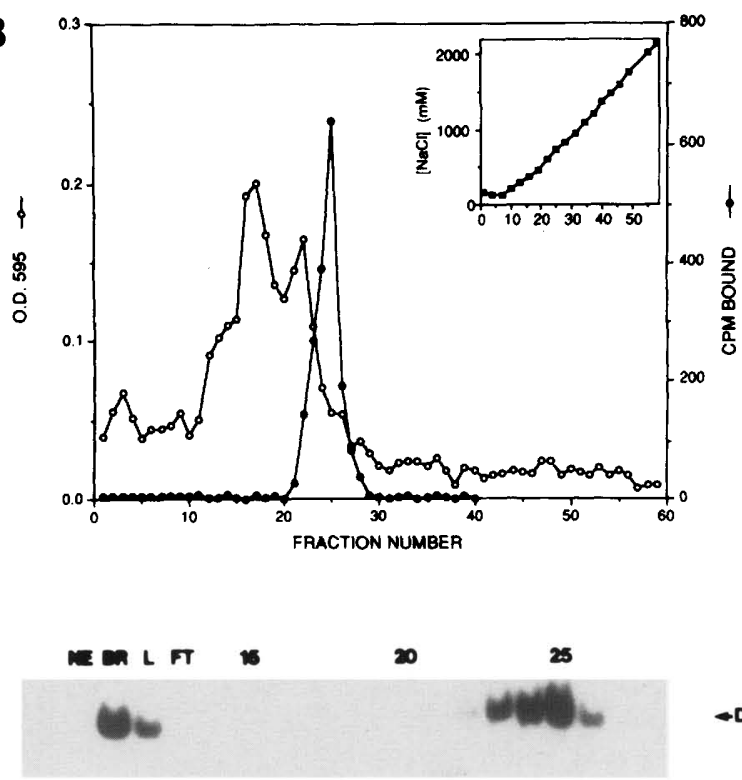

- Dowa.Pr

Figure 7. Fractionation of nonamer-binding activity. $(A)$ Chromatography on Bio-Rex-70. Protein was precipitated from nuclear extract in $50 \%$ saturating $\left(\mathrm{NH}_{4}\right)_{2} \mathrm{SO}_{4}$ and loaded onto Bio-Rex-70 in a buffer containing $50 \mathrm{~mm} \mathrm{NaCl}$. The column was developed with a linear gradient of $\mathrm{NaCl}$ from 50 to 600 mM. (Top) An aliquot $(2 \mu \mathrm{l})$ of each fraction was assayed for binding to the labeled, $27-\mathrm{bp} \mathrm{J}_{\mathrm{K}} 4$ probe by the standard mobility shift assay, in the presence of $100 \mathrm{ng}$ poly[d(I-C)]. The amount of radioactivity present as NBP-DNA complex $(0)$ was quantitated by scintillation spectrometry. Protein $(O)$ was assayed by the Bradford assay. (Inset) The concentration of $\mathrm{NaCl}$ in each column fraction. (Bottom) Assay of column fractions for DNAbinding activity. Assays were performed as described above. DNA-protein complexes were detected by autoradiography. (Lane NE) No extract added; (lane E) $2 \mu$ l of partially purified NBP, from a prior small-scale preparation; (lane $L) 2 \mu l$ of the loaded fraction; (lanes 15-31) elution fractions from the BioRex-70 column. (B) Chromatography of NBP on heparin agarose. The Bio-Rex-70 activity pool was diluted twofold and loaded onto a heparin-agarose column. The column was developed with a linear gradient of $\mathrm{NaCl}$ from $50 \mathrm{~mm}$ to $2.3 \mathrm{M}$. (Top) Fractions were assayed for specific DNA binding activity (O) and protein $(O)$ as described in $A$. (Inset) The concentration of $\mathrm{NaCl}$ in each column fraction. (Bottom) Assay of column fractions for DNA binding activity. Assays were performed as described in $A$ ). (Lane $N E$ ) No extract added; (lane $B R) 2 \mu l$ active pool from Bio-Rex-70; (lane L) $2 \mu$ l of the loaded material; (lane FT) $2 \mu l$ of the flowthrough; (lanes 14-29) elution fractions from the heparin-agarose column. The position of the NBP-DNA complex is indicated. $(C)$ Chromatography of NBP on nonspecific DNASepharose. The heparin agarose activity pool was dialyzed against a buffer containing $50 \mathrm{mM} \mathrm{NaCl}$ and loaded onto a nonspecific DNA-Sepharose column. The column was developed with a linear gradient of $\mathrm{NaCl}$ from $50 \mathrm{~mm}$ to $2.5 \mathrm{M}$. (Top) Fractions were assayed for specific DNA binding activity $(O)$ and protein $(O)$, as described in $A$. (Inset) The concentration of $\mathrm{NaCl}$ in each column fraction. (Bottom) Assay of column fractions for DNA binding activity. Assays were performed as described in $A$. (Lane $N E$ ) No extract added; (lane $L) 2 \mu \mathrm{l}$ of the loaded material; (lane FT) $2 \mu \mathrm{l}$ of the flowthrough; (lanes 1-17) elution fractions from the nonspecific DNA-Sepharose column. The position of the NBP-DNA complex is indicated.

tion were determined by a calculation of the native molecular weight and frictional ratio, according to the method of Siegel and Monty (1966). This calculation is based on two experimentally derived parameters: sedimentation coefficient $\left(S_{20, w}\right)$ and Stokes' radius $\left(r_{s}\right)$. Ve- locity sedimentation analysis of NBP in $0.5 \mathrm{M} \mathrm{NaCl}$ yielded a sedimentation coefficient of 4.0S (Fig. 9A). By analytic gel filtration on Superose 12, we determined the Stokes' radius of NBP to be $31.5 \times 10^{-8} \mathrm{~cm}$ (Fig. 9B). Assuming a partial specific volume of $0.725 \mathrm{~cm}^{3} / \mathrm{g}$, we 

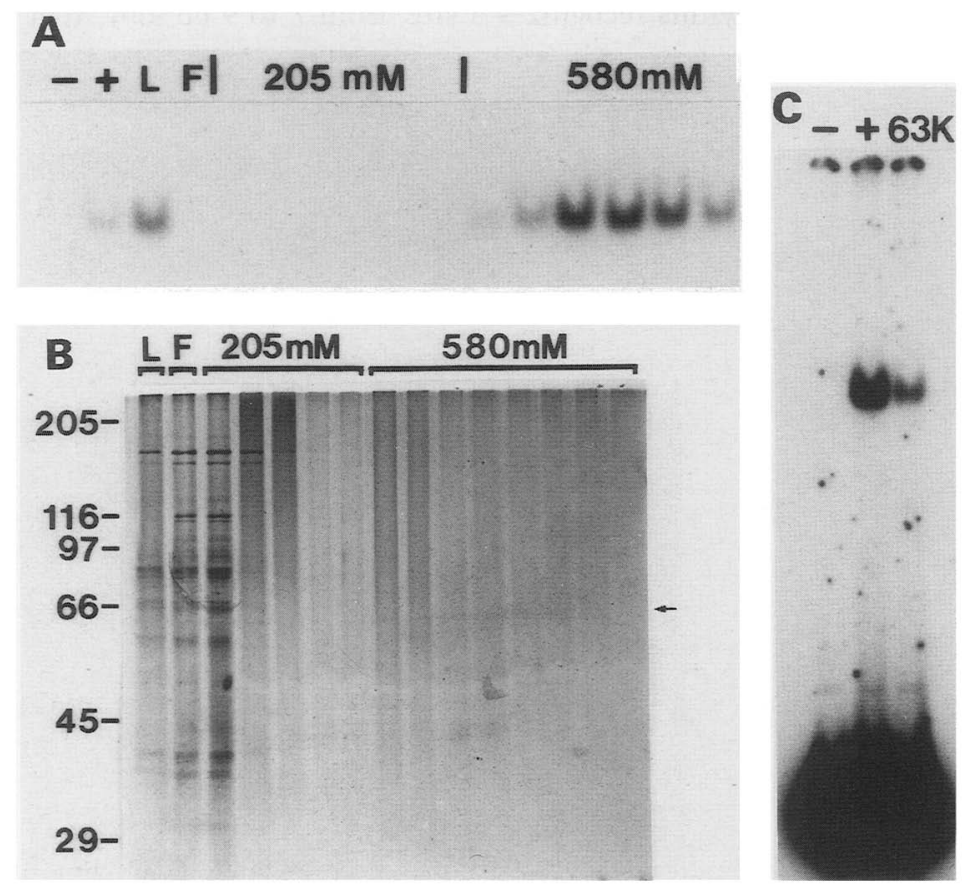

Figure 8. Purification of NBP by nonamer affinity chromatography. $(A)$ Assay of column fractions for DNA binding activity. The activity pool from nonspecific DNA-Sepharose was concentrated fivefold, dialyzed against binding buffer, and loaded onto a nonamer DNA affinity column in the presence of poly[d(I-C)], as described in Methods. The column was washed with $15 \mathrm{ml}$ of binding buffer containing $205 \mathrm{~mm}$ $\mathrm{NaCl}$, and activity was eluted by passage of 10 $\mathrm{ml}$ of binding buffer containing $580 \mathrm{mM} \mathrm{NaCl}$. The volume of each fraction was $1 \mathrm{ml}$. Fractions were assayed for DNA binding activity as described in Fig. 7. (Lane - ) No extract added; (lane $+\mid 2 \mu$ l of Bio-Rex-70 activity pool; (lane $L$ ) $2 \mu \mathrm{l}$ of the loaded material; (lane $F$ ) $2 \mu \mathrm{l}$ flowthrough; (lanes $205 \mathrm{~mm}$ ) $2 \mu$ l from fractions $1,4,7,10$, and 13 , which were eluted with 205 $\mathrm{mM} \mathrm{NaCl}$; (lanes $580 \mathrm{mM}$ ) $2 \mu \mathrm{l}$ from fractions 16-11, which were eluted with $580 \mathrm{~mm} \mathrm{NaCl}$. (B) SDS-polyacrylamide gel electrophoresis of fractions from the nonamer DNA affinity column. An aliquot of each column fraction was precipitated by addition of trichloroacetic acid (TCA) to $17 \%$ and deoxycholate (DOC) to 0.7 $\mathrm{mg} / \mathrm{ml}$, followed by incubation on ice for $15 \mathrm{~min}$.

Protein was collected by centrifugation at $12,000 \mathrm{~g}$ for $20 \mathrm{~min}$ at $4^{\circ} \mathrm{C}$, dissolved in $15 \mu \mathrm{l}$ of sample buffer, neutralized by the addition of Tris base ( $\mathrm{pH} \mathrm{9.0),} \mathrm{heated} \mathrm{at} 95^{\circ} \mathrm{C}$ for $10 \mathrm{~min}$, and fractionated by SDS-polyacrylamide gel electrophoresis. Protein was detected by silver staining. (Lane $L$ ) Twenty microliters of the material loaded onto the affinity column; (lane $F$ ) $500 \mu l$ of the flowthrough fraction; (lanes $205 \mathrm{~mm}$ ) $500 \mu \mathrm{l}$ of fractions 1, 4, 7, 10, and 13; (lanes $580 \mathrm{~mm}$ ) $500 \mu \mathrm{l}$ of fractions 16-23. The arrow indicates the position of the $63-\mathrm{kD}$ species. (Left) The positions and apparent molecular weights of standards (in $\mathrm{kD}$ ). (C) The 63-kD polypeptide has nonamer binding activity. Aliquots $(100 \mu l)$ of fractions $16-20$ from the affinity column were pooled and precipitated with $17 \%$ TCA in the presence of $0.7 \mathrm{mg} / \mathrm{ml} \mathrm{DOC}$, as described above. The protein pellet was dissolved in $15 \mu l$ of sample buffer, neutralized, heated to $95^{\circ} \mathrm{C}$, and fractionated by electrophoresis through SDS-polyacrylamide alongside a sample of each elution fraction. The portion of the gel containing the pooled protein was removed, and the remainder of the gel was stained with silver. The gel lane containing the pooled protein was aligned with the stained gel, and a 2-mm slice, corresponding to the $63-\mathrm{kD}$ species, was excised. Protein was eluted and renatured as described in Methods. The renatured protein was assayed for binding to the $35-\mathrm{bp}$ EcoRI-HinPI probe from $\mathrm{J}_{\mathbf{K}} 4$ (Lane - I No protein added; (lane $+\mid 2 \mu$ l Bio-Rex-70 activity pool; (lane 63K) $5 \mu$ l renatured $63-\mathrm{kD}$ protein ( $1 \%$ of the renatured sample).

estimate the native molecular mass of NBP to be $53 \mathrm{kD}$, with a frictional ratio $\left(\mathrm{f} / \mathrm{f}_{0}\right)$ of 1.27 . These results suggest that NBP exists as a globular monomer in $0.5 \mathrm{M} \mathrm{NaCl}$.

\section{Discussion}

The structural features of immunoglobulin gene rearrangement suggest a mechanism in which participating DNA segments are cleaved at the junction between the heptamer and the coding sequence, to yield an intermediate in which four DNA ends - two coding ends and two flanking ends-are held in proximity (MorzyckaWroblewska et al. 1988). From a consideration of the structures of aberrant rearrangement products, it is apparent that a heptamer element, in the absence of an intact nonamer, can mediate joining at a very low frequency (Kleinfield et al. 1986; Reth et al. 1986). It is nonetheless clear that the nonamer element plays an intimate role in rearrangement. Experiments presented here demonstrate that deletion of the nonamer is associated with at least a 50 -fold decrease in the frequency of rearrangement in vivo. In addition, rearrangement is constrained by the spatial relationship between the heptamer and nonamer elements, as evidenced by the observation that recombination generally occurs between gene segments that carry nonamer elements at specific distances ( 12 and $23 \mathrm{bp}$ ) from the heptamer.

One interpretation of these observations is that the heptamer and nonamer elements are recognized by separate components of the recombinational apparatus and that efficient rearrangement requires interaction between these components. For example, we might imagine that the binding of a protein(s) to the nonamer stabilizes an interaction between a specific endonuclease and the heptamer, via protein-protein contacts. Another possibility, not exclusive of the first, is that interactions between nonamer binding proteins are involved in the appropriate pairing of immunoglobulin or TCR gene segments. If the nonamer element represents the binding site for a specific component of the recombinational apparatus, why do individual nonamer sequences exhibit such apparent variability? One answer may be that these sequence differences lead to differences in affinity and consequently in the frequency of 


\section{A}

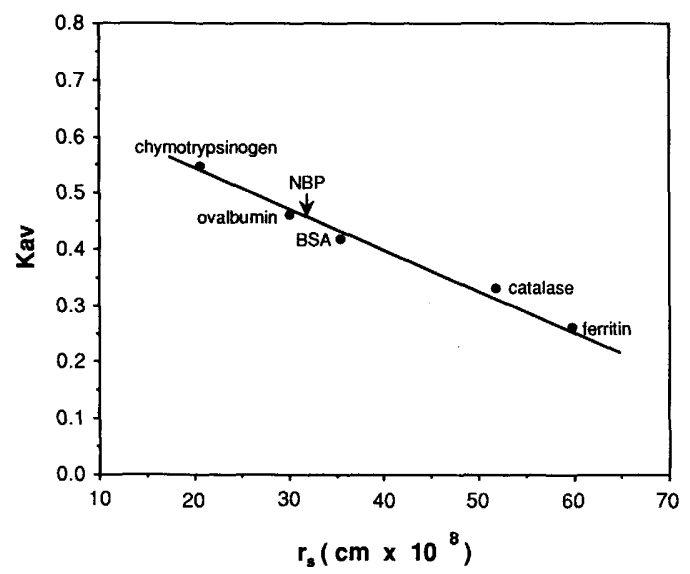

B

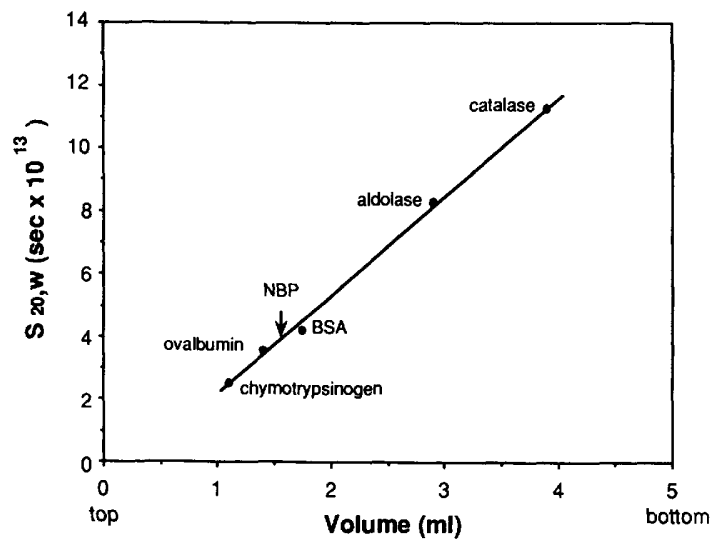

Figure 9. Hydrodynamic properties of NBP $(A)$ Determination of Stokes' radius. Protein $(4 \mu \mathrm{g})$ from the DNA-Sepharose activity pool was fractionated by gel filtration on a Superose- 12 FPLC HR 10/30 column, as described in Methods. Fractions ( $250 \mu \mathrm{l}$ ) were assayed for DNA binding activity. Standards were detected by absorbance at $280 \mathrm{~nm}$ and by Bradford assay. The partition coefficient, $K_{a v}$, was calculated for each species from its elution volume, the void volume of the column $\left(V_{0}\right)$, and the total volume of the column $\left(V_{t}\right)$, according to the equation

$$
K_{\mathrm{av}}=\frac{V_{\mathrm{e}}-V_{0}}{V_{\mathrm{t}}-V_{0}}
$$

where $V_{0}=7.1 \mathrm{ml}, V_{t}=20.3 \mathrm{ml}$, and $V_{e}$ is the elution volume. $V_{o}$ was determined from the elution volume of dextran blue. The partition coefficients of standards are plotted as a function of Stokes' radius $\left(r_{s}\right)$. The $K_{a v}$ for NBP, which corresponds to a Stokes' radius of $31.5 \times 10^{-8} \mathrm{~cm}$, is indicated on the standard curve. $(B)$ Determination of Svedberg constant. Protein $(1.5 \mu \mathrm{g})$ from the nonspecific DNA-Sepharose activity pool was combined with standards and sedimented through a 4.9-ml, linear $15-30 \%$ glycerol gradient, as described in Methods. Fractions (100 $\mu$ l) were assayed for DNA binding activity, and standards were localized by SDS-polyacrylamide gel electrophoresis and staining with Coomassie blue. The sedimentation coefficients of standards $\left(\mathrm{S}_{20, \mathrm{w}}\right)$ are plotted as a function of gradient volume. The position of NBP, which corresponds to a sedimentation coefficient of $4 \times 10^{-13} \mathrm{sec}$, is indicated on the standard curve.

rearrangement. Such a mechanism would allow evolution to adjust the immunological repertoire by altering the sequence of a specific, cis-acting DNA element.

The DNA-binding protein that we have purified from calf thymus recognizes a site, from 7 to $9 \mathrm{bp}$ long, that coincides with the conserved nonamer. In addition to its presence in thymus, previous experiments identified a similar binding activity in extracts of two immature Blymphoid cell lines but not in extracts of two fibroblastoid cell lines nor in an erythroleukemia cell line (Halligan and Desiderio, 1987 and B. Halligan and S.V. Desiderio, unpubl.). Thus, nonamer binding activity is not ubiquitous and appears to be preferentially expressed in lymphoid cells. On the basis of its sequence specificity, its preferential expression in lymphoid cells, and the profound impairment of rearrangement upon deletion of its binding site, it seems likely that NBP is a component of the recombinational apparatus that assembles immunoglobulin and TCR genes.

The mutations we placed within the nonamer element reduced the affinity of DNA fragments for NBP by a factor of 300 - to at least 1000 -fold, relative to the affinity of the wild-type fragment. These decreases in affinity correspond to decreases in binding free energy, ranging from 3.4 to $>4.1 \mathrm{kcal} / \mathrm{mole}$, and are comparable to the energy of a hydrogen bond $(\sim 3-6 \mathrm{kcal} / \mathrm{mole})$ (Saenger 1984). DNA fragments carrying 3-bp substitutions in the spacer region had $\sim 10$-fold lower affinity for NBP than the wild-type substrate. Although the effects of these mutations are far smaller than the effects of mutations within the nonamer, this observation suggests that NBP may also interact, albeit weakly, with nucleotides within the spacer region. Interestingly, the spacer mutations that we tested overlap a 3-bp motif, PuGG, that lies $2 \mathrm{bp}$ from the nonamer in most immunoglobulin and TCR spacer regions (see Fig. 1). Whether mutation of this motif affects rearrangement has not yet been determined.

Because immunoglobulin gene rearrangement is apparently initiated by specific cleavage of DNA at the junction of heptamer and coding sequences, we assayed NBP for specific (heptamer-directed) and nonspecific endonucleolytic activity and found NBP to possess neither (M. Li and S.V. Desiderio, unpubl.). If separate components of the recombinational apparatus act at the nonamer and the heptamer, as we have argued above, then the lack of associated endonucleolytic activity is not surprising. In light of these considerations, it will be of interest to determine whether the binding of NBP renders immunoglobulin recombinational signal sequences susceptible to site-specific endonucleolytic or strand-exchange activities.

NBP is apparently a rare component of thymic nuclei. On the basis of an upper limit of $11 \mu \mathrm{g}$ of protein recovered in the affinity chromatography step and a $22 \%$ overall yield of nonamer binding activity, we estimate that NBP represents $<0.005 \%$ of protein in the crude nuclear extract. The scarcity of NBP is consistent with action at a relatively small number of sites, as would be expected were NBP to function in immunoglobulin and TCR gene rearrangement. Experiments described here further demonstrate the efficacy of recognition site affinity chromatography, in conjunction with conventional chromatographic methods, in purification of rare 
Li et al.

DNA-binding proteins. The availability of affinity-purified NBP will facilitate functional studies, not least by providing peptide sequence information that should be useful in identifying the gene for NBP.

\section{Methods}

\section{DNA constructions}

Mutant and wild-type substrates for protein binding. Complementary, 24-nucleotide-long oligonucleotide pairs (NM1/ NM2, NM3/NM4, NM5/NM6, NM7/NM8, NM9/NM10, NM11/NM12, NM13/NM14, NM60/NM61, and NM62/ NM63; Fig. 2) were synthesized by the phosphoramidite method (Beaucage and Caruthers 1981), using the Applied Biosystems model $380 \mathrm{~B}$ automated synthesizer. Tritylated oligonucleotides were isolated by reverse-phase chromatography on an octadecylsulfate $(\mathrm{C} 18)$ column (Keystone Scientific). Complementary strands were annealed as described (Kadonaga and Tjian 1986), and the resulting duplex DNA, flanked by EcoRI and $B a m H I$ restriction sites, was introduced into the plasmid pUC13. The resulting plasmids were designated $\mathrm{pNM} 1 / 2$, pNM3/4, pNM5/6, pNM7/8, pNM9/10, pNM11/12, pNM13/ 14 , pNM60/61, and pNM62/63. The DNA sequence of each of the cloned fragments was verified by the dideoxynucleotide chain-termination method (Sanger et al. 1977). The construction of plasmid $\mathrm{pJ}_{\mathrm{K}} 4$.copy 96 , which contains multiple tandem copies of the wild-type $\mathrm{J}_{\mathrm{K}} 4$ heptamer-spacer-nonamer sequence, has been described (Halligan and Desiderio 1987).

Substrates for immunoglobulin gene rearrangement. Construction of the plasmid pLJHCR-2 (Fig. 5), which was used as a substrate for rearrangement of wild-type immunoglobulin gene segments in vivo, has been described (Morzycka-Wroblewska et al. 1988). The $V_{H}$ segment of the plasmid pLJHCR-2 $\Delta N$ (Fig. 5) is identical to that of pLJHCR-2, except for an 18-bp deletion that encompasses $2 \mathrm{bp}$ of spacer sequence, the entire nonamer, and $7 \mathrm{bp}$ of 3 '-flanking sequence.

All plasmids were propagated as monomers in the E. coli strain DH1 (Hanahan 1983). Plasmid DNA was prepared by a detergent lysis procedure (Bothwell et al. 1981) and purified over two $\mathrm{CsCl}$ equilibrium gradients.

\section{Biochemical assays}

Specific binding of protein to DNA. The formation of specific DNA-protein complexes was detected by a modification of the electrophoretic mobility shift assay of Strauss and Varshavsky, as described (Halligan and Desiderio 1987). Wild-type DNA probes used in these assays were either a 27-bp DdeI-HinPI or a 35-bp EcoRI-HinPI DNA fragment from $\mathrm{pJ}_{\mathrm{k}}$ 4.copy96. To prepare the probes, $\mathrm{pI}_{\mathrm{K}} 4$.copy 96 was digested with the appropriate restriction endonucleases; the products were dephosphorylated by treatment with calf intestinal alkaline phosphatase and radiolabeled with $\left[\gamma^{-32}\right.$ P]ATP by T4 polynucleotide kinase. The labeled DNA probes, which carry the nonamer sequence of $J_{K} 4$, were purified by polyacrylamide gel electrophoresis. The specific activity of the probes was typically $\sim 2000 \mathrm{Ci} / \mathrm{mmole}$.

Binding reactions $(20 \mu l)$ contained labeled DNA fragment, binding buffer ( $80 \mathrm{~mm} \mathrm{NaCl}, 10 \mathrm{mM}$ HEPES- $\mathrm{NaOH}$ (pH 7.5), 40 $\mathrm{mM}\left(\mathrm{NH}_{4}\right)_{2} \mathrm{SO}_{4}, 10 \mathrm{~mm}$ 2-mercaptoethanol, $1 \mathrm{mM}$ EDTA, $4 \%$ (wt/vol) glycerol, $0.1 \%$ Triton X-100], $30 \mathrm{ng}$ poly[d(I-C)] and $2 \mu \mathrm{l}$ of protein. In some experiments, a second competitor DNA was included at varying concentrations. Standard binding assays contained $0.1 \mathrm{ng}$ of labeled DNA fragment; competition assays contained $0.01 \mathrm{ng}$ of labeled fragment. After $30 \mathrm{~min}$ incubation at room temperature, $5 \mu \mathrm{l}$ of assay buffer, supplemented with $50 \%$ glycerol, $0.1 \%$ bromphenol blue, and $0.1 \%$ xylene cyanol, was added. Reaction products were fractionated by electrophoresis through a $6 \%$ polyacrylamide slab gel $(16 \mathrm{~cm} \times 1.5 \mathrm{~mm})$ in $33.5 \mathrm{~mm}$ Tris- $\mathrm{HCl}(\mathrm{pH} 7.5), 16.5 \mathrm{~mm}$ sodium acetate, and 5 $\mathrm{mM}$ EDTA. Electrophoresis was carried out at $110 \mathrm{~V}$ for $2 \mathrm{hr}$ at room temperature. Radioactivity was detected by autoradiog. raphy. The amount of DNA present in specific DNA-protein complexes was quantitated indirectly, by densitometric analysis of autoradiographs, and directly, by scintillation spectrometry of the species excised from polyacrylamide gels; the values obtained by these two methods were similar. One unit of binding activity is defined as the amount required to bind 1 fmole of the $27-\mathrm{bp} \mathrm{J}_{\mathrm{K}} 4$ probe in the standard electrophoretic assay.

SDS-polyacrylamide gel electrophoresis. SDS-polyacrylamide gel electrophoresis was performed as described (Laemmli 1970). Sample buffer contained $100 \mathrm{~mm}$ 2-mercaptoethanol, 60 $\mathrm{mM}$ Tris-HCl $\{\mathrm{pH} 6.8), 10 \%$ glycerol (wt/vol), $1 \%$ SDS, and $0.0005 \%$ bromphenol blue. Molecular weight standards (Sigma) were myosin (205 kD), $\beta$-galactosidase $(116 \mathrm{kD})$, phosphorylase B (97.4 kD), BSA (66 kD), ovalbumin (45 kD), and carbonic anhydrase $(29 \mathrm{kD})$. Protein was detected by silver stain (Rapid-AgStain, ICN).

Recovery and renaturation of protein from SDS-polyacrylamide gels. After electrophoresis, lanes containing protein were cut into $10-\mathrm{mm}$-wide slices and crushed into a paste. Protein was eluted by incubating the gel paste with a buffer containing $150 \mathrm{~mm} \mathrm{NaCl}, 20 \mathrm{~mm}$ HEPES-NaOH (pH 7.5), $5 \mathrm{~mm}$ DTT, $0.1 \mathrm{~mm}$ EDTA, $0.1 \%$ SDS, and $0.1 \mathrm{mg} / \mathrm{ml} \mathrm{BSA}$ for $3 \mathrm{hr}$ at room temperature. Protein was renatured by the method of Hager and Burgess (1980), with modifications. After elution from SDS-polyacrylamide, protein was precipitated by addition of 4 volumes of cold $\left(-20^{\circ} \mathrm{C}\right)$ acetone and incubation for 45 $\mathrm{min}$ in a dry-ice/ethanol bath. Protein was collected by centrifugation at $12,000 \mathrm{~g}$ for $15 \mathrm{~min}$. The pellet was washed with a solution containing $80 \%$ acetone, $20 \%$ dilution buffer $[150 \mathrm{mM}$ $\mathrm{NaCl}, 20 \mathrm{~mm}$ HEPES-NaOH (pH 7.5), $5 \mathrm{~mm}$ DTT, $0.1 \mathrm{~mm}$ EDTA, and $0.1 \mathrm{mg} / \mathrm{ml} \mathrm{BSA}$ ], dried, dissolved in $5 \mu \mathrm{l}$ of dilution buffer supplemented with $6 \mathrm{M}$ guanidine- $\mathrm{HCl}$, and incubated at room temperature for $20 \mathrm{~min}$. The solution was then diluted 50 -fold with dilution buffer and incubated for an additional 12 $\mathrm{hr}$ at room temperature.

Glycerol gradient sedimentation. The active fraction from nonspecific DNA-Sepharose $(0.75 \mu \mathrm{g}$ protein) was combined with sedimentation standards [40 $\mu \mathrm{g}$ of each catalase $(11.3 \mathrm{~S}$ ), aldolase (8.3S), BSA (4.2S), ovalbumin (3.6S), and chymotrypsinogen (2.5S)] in $100 \mu$ l buffer $\mathrm{G}$ [0.5 M NaCl, $10 \mathrm{mM}$ HEPES$\mathrm{NaOH}$ (pH 7.5), $10 \mathrm{~mm}$ 2-mercaptoethanol, $5 \mathrm{~mm}$ EDTA, 0.5 $\mathrm{mM}$ PMSF] and layered onto a $4.9-\mathrm{ml}$ linear $15-30 \%$ glycerol gradient that was prepared in buffer $\mathrm{G}$. The gradient was spun in a Beckman SD 50.1 rotor at $45,000 \mathrm{rpm}$ for $26 \mathrm{hr}$ at $4^{\circ} \mathrm{C}$. After centrifugation, $100 \mu \mathrm{l}$ fractions were collected. A 2- $\mu$ l aliquot of each fraction was assayed for specific DNA-binding activity. To determine positions of the standards, a $15-\mu l$ aliquot of each fraction was analyzed by SDS-polyacrylamide gel electrophoresis and staining with Coomassie blue.

Superose-12 gel filtration chromatography. An aliquot of the active fraction from nonspecific DNA-Sepharose $14 \mu \mathrm{g}$ of protein in $100 \mu \mathrm{l}$ ) was loaded onto a Superose-12 FPLC HR 10/30 column (Pharmacia), which had been equilibrated in buffer $B$ (see below), supplemented with $0.5 \mathrm{M} \mathrm{NaCl}$. Protein was eluted in the same buffer at a flow rate of $12 \mathrm{ml} / \mathrm{hr}, 5 \mu \mathrm{l}$ of each $250 \mu \mathrm{l}$ 
fraction was assayed for binding activity. Standards used were ferritin $\left(r_{s} 61.0 \times 10^{-8} \mathrm{~cm}\right)$, catalase $\left(r_{s} 52.2 \times 10^{-8} \mathrm{~cm}\right)$, BSA $\left(r_{s} 35.5 \times 10^{-8} \mathrm{~cm}\right)$, ovalbumin $\left(r_{s} 30.5 \times 10^{-8} \mathrm{~cm}\right)$, and chymotrypsinogen $\left(r_{s} 20.9 \times 10^{-8} \mathrm{~cm}\right)$.

Protein assay. Protein concentrations were determined by the method of Bradford (1976). BSA was used as a standard.

DNA assay. DNA fragments used as probes and competitors in binding experiments were quantitated fluorimetrically after staining with the dye Hoechst 33258 .

\section{Purification of NBP}

Materials. Calf thymus was obtained from a local slaughterhouse. T4 polynucleotide kinase and T4 DNA ligase were obtained from New England Biolabs. Sepharose CL-2B was purchased from Pharmacia, Bio-Rex-70 (200-400 mesh) from Bio$\mathrm{Rad}$, and heparin agarose from BRL. $\mathrm{CNBr}$ was obtained from Boehringer-Mannheim. Radioisotopes were supplied by $\mathrm{Du}$ Pont-NEN.

Measurement of $\mathrm{NaCl}$ concentration. The concentration of $\mathrm{NaCl}$ in column fractions was determined by measuring conductivity in comparison to a standard curve.

Buffers used in the purification. Buffer B is $50 \mathrm{mM} \mathrm{NaCl}, 20$ mM HEPES- $\mathrm{NaOH}$ (pH 7.5), $10 \mathrm{~mm}$ 2-mercaptoethanol, $2 \mathrm{~mm}$ EDTA, $0.2 \mathrm{mM}$ PMSF, $10 \%$ (wt/vol) glycerol. Buffer E is 250 mM sucrose, $100 \mathrm{~mm} \mathrm{NaCl}, 50 \mathrm{~mm}$ HEPES-NaOH $(\mathrm{pH} 7.5), 10$ mM 2-mercaptoethanol, $0.2 \mathrm{~mm}$ PMSF. Buffer $\mathrm{H}$ is $250 \mathrm{~mm}$ sucrose, $50 \mathrm{~mm}$ HEPES- $\mathrm{NaOH}(\mathrm{pH} 7.5), 25 \mathrm{~mm} \mathrm{KCl}, 10 \mathrm{~mm}$ 2mercaptoethanol, $5 \mathrm{mM} \mathrm{MgCl}_{2}, 0.2 \mathrm{mM}$ PMSF. Buffer $\mathrm{N}$ is 80 $\mathrm{mM} \mathrm{NaCl}, 40 \mathrm{mM}\left(\mathrm{NH}_{4}\right)_{2} \mathrm{SO}_{4}, 10 \mathrm{~mm}$ HEPES-NaOH $(\mathrm{pH} 7.5), 10$ mM 2-mercaptoethanol, $5 \mathrm{mM}$ EDTA, $0.2 \mathrm{mM}$ PMSF, 4\% (wt/ vol) glycerol. Buffer $\mathrm{P}$ is $50 \mathrm{mM}$ Tris- $\mathrm{HCl}(\mathrm{pH} 8.0), 10 \mathrm{~mm}$ $\mathrm{MgCl}_{2}, 5 \mathrm{~mm}$ DTT, $1 \mathrm{~mm}$ spermidine, $0.1 \mathrm{~mm}$ EDTA. Ligation buffer is $50 \mathrm{~mm}$ Tris- $\mathrm{HCl}$ (pH 7.5), $10 \mathrm{~mm} \mathrm{MgCl}, 10 \mathrm{~mm}$ DTT, $1 \mathrm{mM}$ spermidine, $2 \mathrm{mM} \mathrm{ATP}, 0.01 \%$ (wt/vol) BSA.

Preparation of nonspecific DNA-Sepharose. DNA was conjugated to Sepharose as described by Alberts and Herrick (1971), with modifications. Sepharose CL-2B (wet volume $25 \mathrm{ml}$ ) was washed with water and resuspended in water to give a $50-\mathrm{ml}$ slurry. Activation was performed in an ice-water bath. Cyanogen bromide (4 gm) was dissolved in $3 \mathrm{ml}$ dimethylformamide and added dropwise to the slurry. The $\mathrm{pH}$ value of the reaction was maintained between 11.0 and 11.5 by addition of 5 $\mathrm{N} \mathrm{NaOH}$. When the $\mathrm{pH}$ value became steady lafter $\sim 5 \mathrm{~min}$ on ice), the reaction was stopped with $400 \mathrm{ml}$ of ice-cold water. The resulting CNBr-derived Sepharose was washed with $500 \mathrm{ml}$ of water followed by $500 \mathrm{ml}$ of $10 \mathrm{mM} \mathrm{KH} \mathrm{KO}_{4} / \mathrm{K}_{2} \mathrm{HPO}_{4}(\mathrm{pH} 8.0)$ buffer. The coupling reaction was immediately carried out by resuspending the activated Sepharose in $45 \mathrm{ml} 10 \mathrm{mM} \mathrm{KH}_{2} \mathrm{PO}_{4} /$ $\mathrm{K}_{2} \mathrm{HPO}_{4}$ buffer (pH 8.0 ) containing $6 \mathrm{mg}$ of sheared salmon sperm DNA and incubating at room temperature for $12 \mathrm{hr}$ on a rotary shaker. Coupling efficiency was estimated at $76 \mu \mathrm{g}$ $\mathrm{DNA} / \mathrm{ml}$ matrix. DNA-Sepharose was washed with $500 \mathrm{ml}$ water, followed by $500 \mathrm{ml} 0.1 \mathrm{M}$ ethanolamine- $\mathrm{HCl}(\mathrm{pH} 8.0)$. Any activated sites remaining were blocked by incubation with $40 \mathrm{ml}$ of $0.1 \mathrm{M}$ ethanolamine- $\mathrm{HCl}(\mathrm{pH} 8.0)$ at room temperature for $5 \mathrm{hr}$ on a rotary shaker.

Preparation of the nonamer affinity column. The 27-mer oligonucleotides SD7 (5'-AATTCAGGCAGGTTTTTGTAAAGGGGG-3') and SD8 (5'-GATCCCCCCTTTACAAAAACCTGCCTG-3') (300 $\mu \mathrm{g}$ of each) were annealed in $100 \mu$ l P buffer by incubation at $100^{\circ} \mathrm{C}$ for $2 \mathrm{~min}, 65^{\circ} \mathrm{C}$ for $10 \mathrm{~min}, 37^{\circ} \mathrm{C}$ for 10 $\mathrm{min}$, and room temperature for $10 \mathrm{~min}$. The $5^{\prime}$ termini were phosphorylated by addition of $10 \mu \mathrm{l} 30 \mathrm{~mm}\left[\gamma^{-32} \mathrm{P}\right]$ ATP $\langle 0.1$ $\mu \mathrm{Ci} / \mathrm{mmole})$ and $2.5 \mu \mathrm{l} \mathrm{T} 4$ polynucleotide kinase $(400 \mathrm{U} / \mu \mathrm{l})$, followed by incubation at $37^{\circ} \mathrm{C}$ for $2 \mathrm{hr}$. The reaction was stopped by addition of $50 \mu \mathrm{l} 50 \mathrm{~mm}$ EDTA, 2\% SDS. After extraction with phenol and precipitation in ethanol, the DNA pellet was dried in vacuo and resuspended in $100 \mu$ ligation buffer. T4 DNA ligase $(4 \mu \mathrm{l}$ at 10 Weiss $\mathrm{U} / \mu \mathrm{l})$ was added, and the reaction was incubated at $14^{\circ} \mathrm{C}$ for $10 \mathrm{hr}$. Ligation products were extracted with phenol, precipitated in ethanol, dried, and dissolved in $200 \mu \mathrm{l} 10 \mathrm{mM} \mathrm{KH} \mathrm{PO}_{4} / \mathrm{K}_{2} \mathrm{HPO}_{4}$ (pH 8.0), $2 \mathrm{~mm}$ EDTA. Concatermerized DNA was coupled to $8 \mathrm{ml}$ of CNBractivated Sepharose, as described above. The efficiency of coupling, based on the specific activity of the DNA and the radioactivity retained on the resin, was $83 \%(61 \mu \mathrm{g}$ of DNA per milliliter of resin).

Preparation of nuclear extract. All purification steps were performed at $4^{\circ} \mathrm{C}$. Nuclei were prepared from 200 grams calf thymus, as described (Halligan and Desiderio 1987), except that cells were lysed in a Waring blender at medium speed in $500 \mathrm{ml}$ homogenization buffer (buffer H). Nuclei were collected by centrifugation at $1800 \mathrm{~g}$ for $7 \mathrm{~min}$, incubated with $100 \mathrm{ml}$ of buffer $\mathrm{E}$ at $0^{\circ} \mathrm{C}$ for $20 \mathrm{~min}$, and pelleted by centrifugation at $2000 \mathrm{~g}$ for $10 \mathrm{~min}$. The supernatant was designated nuclear extract. The concentration of protein in the nuclear extract was generally $10-15 \mathrm{mg} / \mathrm{ml}$.

Ammonium sulfate precipitation. To the nuclear extract, 0.3 grams of ammonium sulfate per $\mathrm{ml}$ of extract was slowly added with constant stirring. The precipitate was collected by centrifugation at $18,000 \mathrm{~g}$ for $30 \mathrm{~min}$. The pellet was resuspended in 50 $\mathrm{ml}$ buffer B and dialyzed for $10 \mathrm{hr}$ against buffer B. A precipitate that formed during dialysis was removed by centrifugation at $15,000 \mathrm{~g}$ for $30 \mathrm{~min}$. The supernatant was designated crude extract. The concentration of protein in crude extract was typically $15-20 \mathrm{mg} / \mathrm{ml}$.

Bio-Rex-70 chromatography. The crude extract was diluted three-fold with buffer B and loaded onto a Bio-Rex-70 column $(2.5 \times 15 \mathrm{~cm}, 74 \mathrm{ml})$, which had been washed with $600 \mathrm{ml} 2.5$ $\mathrm{M} \mathrm{NaCl}, 100 \mathrm{~mm}$ HEPES- $\mathrm{NaOH}(\mathrm{pH} 7.5)$ and equilibrated with $740 \mathrm{ml}$ buffer B. After loading, the column was washed with $150 \mathrm{ml}$ buffer B. The DNA binding activity was eluted with a linear gradient of $\mathrm{NaCl}$ from 50 to $600 \mathrm{~mm}$ (850 ml). The specific DNA binding activity eluted as a single peak at $280 \mathrm{mM}$ $\mathrm{NaCl}$. Fractions eluting between 260 and $300 \mathrm{~mm} \mathrm{NaCl}$ were pooled and designated the Bio-Rex-70 activity pool (protein concentration, $1.5-2.5 \mathrm{mg} / \mathrm{ml}$; volume, $36 \mathrm{ml}$ ).

Heparin agarose chromatography. The Bio-Rex-70 activity pool was diluted twofold in buffer $\mathrm{B}$ without $\mathrm{NaCl}$. This diluted pool was then loaded onto a heparin-agarose column $(1.5 \times 20$ $\mathrm{cm}, 35 \mathrm{ml}$ ), which had been washed with $200 \mathrm{ml}$ of $2.5 \mathrm{M} \mathrm{NaCl}$ in buffer B and equilibrated with $350 \mathrm{ml}$ of buffer B. After loading, the matrix was washed with $200 \mathrm{ml}$ of buffer B. DNA binding activity was eluted with a $650-\mathrm{ml}$ linear gradient of $\mathrm{NaCl}$ from $50 \mathrm{~mm}$ to $2.3 \mathrm{M}$. Specific binding activity eluted as a single peak at $780 \mathrm{~mm} \mathrm{NaCl}$. Fractions containing activity were pooled (protein concentration, $100-200 \mu \mathrm{g} / \mathrm{ml}$; volume, $45 \mathrm{ml}$ ) and dialyzed for $3 \mathrm{hr}$ against $500 \mathrm{ml}$ buffer B containing $5 \mathrm{~mm}$ EDTA.

Nonspecific DNA-Sepharose chromatography. The dialyzed heparin agarose activity pool was loaded onto a nonspecific DNA-Sepharose column $(1.5 \times 8 \mathrm{~cm}, 14 \mathrm{ml})$, which was equilibrated with $300 \mathrm{ml}$ buffer B, supplemented with $5 \mathrm{~mm}$ EDTA (B-EDTA). After loading, the matrix was washed with $100 \mathrm{ml}$ 
Li et al.

B-EDTA and DNA binding activity was eluted with a linear gradient of $\mathrm{NaCl}$ from $50 \mathrm{~mm}$ to $2.5 \mathrm{M}$. The specific binding activity eluted as a single peak at $300 \mathrm{mM} \mathrm{NaCl}$. Fractions containing DNA binding activity were pooled (protein concentration, $1.5-2.5 \mu \mathrm{g} / \mathrm{ml}$; volume, $7 \mathrm{ml}$ ) and dialyzed against $500 \mathrm{ml}$ of binding buffer.

Recognition site affinity chromatography. The nonamer DNA affinity column $(5 \times 0.5 \mathrm{~cm}, 1 \mathrm{ml})$ was washed with 20 $\mathrm{ml} 2 \mathrm{M} \mathrm{NaCl}$ and equilibrated with $30 \mathrm{ml}$ buffer $\mathrm{N}$. The activity pool from nonspecific DNA-Sepharose was diluted threefold in buffer $\mathrm{B}$ without $\mathrm{NaCl}$. The activity was concentrated by loading onto Bio-Rex-70 and eluting in the reverse direction with buffer B containing $400 \mathrm{mM} \mathrm{NaCl}$. Overall, the activity from nonspecific DNA-Sepharose was concentrated five fold in this step, without detectable loss of activity. The concentrated material was dialyzed against binding buffer, and poly[d(I-C)] was added to a final concentration of $1.5 \mu \mathrm{g} / \mathrm{ml}$. The resulting solution was loaded under gravity onto the nonamer DNA affinity column, and the flowthrough was reloaded three times. After loading, the column matrix was washed with 15 $\mathrm{ml}$ of binding buffer containing $205 \mathrm{mM} \mathrm{NaCl}$. The activity was eluted with $10 \mathrm{ml}$ of binding buffer containing $580 \mathrm{mM} \mathrm{NaCl}$.

\section{Assay for immunoglobulin gene rearrangement}

Cell lines. The Harvey murine sarcoma virus-transformed cell line HAFTL-1 (Alessandrini et al. 1987) was cultured in RPMI 1640 medium supplemented with $10 \%$ fetal calf serum and 50 $\mu$ M 2-mercaptoethanol (RPMI-10). The cell line $\Psi$-2 (Mann et al. 1983) was propagated in Dulbecco's modified Eagle's medium supplemented with $10 \%$ fetal calf serum (DEME-10). Lymphoid cells were cloned by limiting dilution.

Packaging of recombinant retrovirus and transmission to lym. phoid cells. Packaging of the pLJHCR-2 and pLJHCR-2 $\Delta \mathrm{N}$ constructs in the $\Psi-2$ cell line and transmission to the lymphoid cell line HAFTL-1 were performed as described (Desiderio and Wolff 1988), except that G418 was used at a concentration of $1.5 \mathrm{mg} / \mathrm{ml}$ to select for lymphoid cells carrying provirus.

Assay for rearrangement of the LJHCR-2 substrate in the HAFTL-1 cell line. The assay has been described in detail elsewhere (Desiderio and Wolff 1988; Morzycka-Wroblewska et al. 1988 ) and is summarized here. HAFTL-1 cells were infected in duplicate with either the LJHCR-2 or the LJHCR- $2 \Delta \mathrm{N}$ virus. After 10-14 days of selection in RPMI-10 supplemented with $\mathrm{G} 418(1.5 \mathrm{mg} / \mathrm{ml})$, G418-resistant $\left(\mathrm{G} 418^{\mathrm{r}}\right)$ derivatives were apparent. G418 cell populations were expanded to $2 \times 10^{7}$ cells and cloned by limiting dilution in 96-well microtiter plates in RPMI-10 supplemented with $1.5 \mathrm{mg} / \mathrm{ml} \mathrm{G4} 18(0.1 \mathrm{ml}$ per well). After 10-14 days, clones were transferred to $1 \mathrm{ml}$ of the same medium; when cells had achieved a density of $\sim 1 \times 10^{6}$ cells/ $\mathrm{ml}$, cultures were split $1: 2$ and permitted to expand to a density of $\sim 1 \times 10^{6}$ to $2 \times 10^{6} \mathrm{cells} / \mathrm{ml}$.

Genomic DNA was isolated from individual cell clones and assayed for proviral rearrangement. Cells $\left(1 \mathrm{ml}\right.$ at $1 \times 10^{6}$ to $2 \times 10^{6} / \mathrm{ml}$ ) were harvested by centrifugation at $3000 \mathrm{rpm}$ for 5 min in a Dupont Microspin 24S centrifuge. After discarding the supernatant, cell pellets were lysed by addition of $200 \mu l 100$ $\mathrm{mm} \mathrm{NaCl}, 10 \mathrm{~mm}$ Tris- $\mathrm{Cl}$ (pH 8.0), $1 \mathrm{~mm}$ EDTA, 1\% SDS, and $0.4 \mathrm{mg} / \mathrm{ml}$ proteinase $\mathrm{K}$ and incubated for $16 \mathrm{hr}$ at $37^{\circ} \mathrm{C}$. Samples were extracted twice with phenol and twice with ethyl ether. DNA was precipitated by addition of 2 volumes absolute ethanol. Pellets were washed with $1 \mathrm{ml}$ of $70 \%$ ethanol, dried, and dissolved in $200 \mu \mathrm{K} \mathrm{KnI} \mathrm{restriction} \mathrm{endonuclease} \mathrm{buffer} \mathrm{[10}$ $\mathrm{mm} \mathrm{NaCl}, 10 \mathrm{~mm}$ Tris-Cl (pH 7.5), $10 \mathrm{~mm} \mathrm{MgCl}_{2}, 1 \mathrm{~mm}$ DTT,
$100 \mu \mathrm{g} / \mathrm{ml} \mathrm{BSA}$. After the addition of $3 \mu \mathrm{l}$ of $\mathrm{KpnI}$ (30 units), samples were incubated for $16 \mathrm{hr}$ at $37^{\circ} \mathrm{C}$. Reactions were supplemented with $1 \mu \mathrm{l}$ (10 units) additional KpnI, and incubation was continued for $3 \mathrm{hr}$ at $37^{\circ} \mathrm{C}$. Reactions were stopped by addition of $50 \mu \mathrm{l}$ of $2 \%$ SDS, $50 \mathrm{~mm}$ EDTA. After extraction with phenol and precipitation in ethanol, samples were dissolved in $50 \mu \mathrm{l}$ of $10 \%$ glycerol, $5 \mathrm{~mm}$ EDTA, $0.1 \%$ SDS, $0.01 \%$ bromphenol blue, and $0.01 \%$ xylene cyanol. One-half of each sample $\{\sim 20 \mu$ ) was analyzed for rearrangement of proviral DNA by agarose gel electrophoresis, transfer to nitrocellulose, and hybridization to gpt- and neo-specific DNA probes as described (Desiderio and Wolff 1988).

\section{Acknowledgments}

We thank Brian Halligan for advice in the early stages of this work, Clark Riley and Brian Byers for oligonucleotide synthesis, our colleagues in the Department of Molecular Biology and Genetics for stimulating discussions, and Thomas Kelly for his review of the manuscript. The work was supported by grant CA-16519 from the National Institutes of Health and the Howard Hughes Medical Institute.

\section{References}

Akira, S., K. Okazaki, and H. Sakano. 1987. Two pairs of recombination signals are sufficient to cause immunoglobulin V-D-J joining. Science 238: 1134-1138.

Alberts, B. and G. Herrick. 1971. DNA-cellulose chromatography. Methods Enzymol. 21: 198-217.

Alessandrini, A., J.H. Pierce, D. Baltimore, and S.V. Desiderio. 1987. Continuing rearrangement of immunoglobulin and Tcell receptor genes in $\mathrm{Ha}$-ras-transformed lymphoid progenitor cell line. Proc. Natl. Acad. Sci. 84: 1799-1803.

Alt, F.W., T.K. Blackwell, and G.D. Yancopoulos. 1987. Development of the primary antibody repertoire. Science 238: $1079-1087$.

Beaucage, S.L. and M.H. Caruthers. 1981. Deoxynucleoside phosphoramidites-A new class of key intermediates for deoxypolynucleotide synthesis. Tetrahed. Lett. 22: 18591862.

Bernard, O., N. Hozumi, and S. Tonegawa. 1978. Sequences of mouse immunoglobulin light chain genes before and after somatic changes. Cell 15: 1133-1144.

Bothwell, A.L.M., M. Paskind, M. Reth, T. Imanishi-Kari, K. Rajewsky, and D. Baltimore. 1981. Heavy chain variable region contribution to the NPb family of antibodies: Somatic mutation evident in a q2a variable region. Cell 24: 625-637.

Bradford, M. 1976. A rapid and sensitive method for the quantitation of microgram quantities of protein utilizing the principle of protein-dye binding. Anal. Biochem 73: 248-254.

Chen, Y.-H., N. Gascoigne, J. Kavaler, D.I. Cohen, and M.M. Davis. 1984. Somatic recombination in a murine T-cell receptor gene. Nature 309: 322-326.

Cohen, J.B. and D. Givol. 1983. Allelic immunoglobulin $V_{H}$ genes in two mouse strains: Possible germline gene recombination. EMBO I. 2: 2013-2018.

Concannon, P., E. Lai, M. Klein, S. Siu, E. Strauss, L. Pickering, P. Kung, R. Gatti, and L. Hood. 1986. Human T-cell receptor genes: Organization, diversity, and polyphorphism. Cold Spring Harbor Symp. Quant. Biol. 51: 785-795.

Davis, M. 1985. Molecular genetics of the T-cell receptor beta chain. Annu. Rev. Immunol. 3: 537-560.

Desiderio, S.V. and K.R. Wolff. 1988. Rearrangement of exogenous immunoglobulin $\mathrm{V}_{\mathrm{H}}$ and $\mathrm{DJ}_{\mathrm{H}}$ gene segments after retroviral transduction into immature lymphoid cell lines. $I$. Exp. Med. 167: 372-389. 
Early, P., H. Huang, M. Davis, K. Calame, and L. Hood. 1980. An immunoglobulin heavy chain variable region is generated from three segments of DNA: $\mathrm{V}_{\mathrm{H}}, \mathrm{D}$, and $\mathrm{J}_{\mathrm{H}}$. Cell 19: $981-992$.

Hager, D.A. and R.R. Burgess. 1980. Elution of proteins from sodium dodecyl sulfate-polyacrylamide gels, removal of sodium dodecyl sulfate, and renaturation of enzymatic activity: Results with sigma subunit of Escherichia coli RNA polymerase, wheat germ DNA topoisomerase, and other enzymes. Anal. Biochem 109: 76-86.

Halligan, B.D, and S.V. Desiderio. 1987. Identification of a DNA-binding protein that recognizes the nonamer recombinational signal sequence of immunoglobulin genes. Proc. Natl. Acad. Sci. 84: 7019-7023.

Hanahan, D. 1983. Studies on transformation of Escherichia coli with plasmids. J. Mol. Bio. 166: 557-580.

Hayday, A., et al. 1985. Structure, organization, and somatic rearrangement of T-cell gamma genes. Cell 40: 259-269.

Heinrich, G., A. Traunecker, and S. Tonegawa. 1984. Somatic mutation creates diversity in the major group of mouse immunoglobulin kappa light chains. I. Exp. Med. 159: 417435.

Hesse, J., M. Lieber, M. Gellert, and K. Mizuuchi. 1987. Extrachromosomal DNA substrates in pre-B cells undergo inversion or deletion at immunoglobulin V-D-J joining signals. Cell 49: 775-783.

Ichihara, Y., H. Matsuoki, and Y. Kurosawa. 1988. Organization of human immunoglobulin heavy chain diversity gene loci. EMBO J. 7: 4141-4150.

Kabat, E.A., T.T. Wu, M. Reid-Miller, H.M. Perry, and K.S. Gottesman. 1987. Sequences of proteins of immunological interest, 4th ed. U.S. Dept. of Health and Human Services, Washington, D.C.

Kadonaga, J.T. and R. Tjian. 1986. Affinity purification of sequence-specific DNA binding proteins. Proc. Natl. Acad. Sci. 83: 5889-5893.

Kleinfield, R., R.R. Hardy, D. Tarlinton, J. Dangl, L.A. Herzenberg, and M. Weigert. 1986. Recombination between an expressed immunoglobulin heavy-chain gene and a germline variable gene segment in a Lyl + B-cell lymphoma. Nature 322: $843-846$.

Laemmli, U.K. 1970. Cleavage of structural proteins during the assembly of the head of bacteriophage T4. Nature 227: 680685.

LeFranc, M., A. Forster, R. Baer, M.A. Stinson, and T.H. Rabbitts. 1986. Diversity and rearrangement of the human Tcell rearranging gamma genes: Nine germ-line variable genes belonging to two subgroups. Cell 45: 237-246.

Lewis, S., A. Gifford, and D. Baltimore. 1985. DNA elements are asymmetrically joined during site-specific recombination of kappa immunoglobulin genes. Science 228: 677685.

Litman, G.W., L. Berger, K. Murphy, R. Litman, K. Hinds, and B.W. Erickson. 1985. Immunoglobulin $\mathrm{V}_{\mathrm{H}}$ gene structure and diversity in Heterodontus, a phylogenetically primitive shark. Proc. Natl. Acad. Sci. 82: 2082-2086.

Mann, R., R.C. Mulligan, and D. Baltimore. 1983. Construction of a retrovirus packaging mutant and its use to produce helper-free defective retroviruses. Cell 33: 153-159.

Max, E.E., J.G. Seidman, and P. Leder. 1979. Sequences of five potential recombination sites encoded close to an immunoglobulin kappa constant region gene. Proc. Natl. Acad. Sci. 76: 3450-3454.

Max, E.E., J.G. Seidman, H. Miller, and P. Leder. 1980. Variation in the crossover point of kappa immunoglobulin gene
V-J recombination: Evidence from cryptic genes. Cell 21: 793-799.

Morzycka-Wroblewska, E., F.E.H. Lee, and S.V. Desiderio. 1988. Unusual immunoglobulin gene rearrangement leads to replacement of recombinational signal sequences. Science 242: $261-263$.

Okazaki, K., D.D. Davis, and H. Sakano. 1987. T-cell receptor beta gene sequences in the circular DNA of thymocyte nuclei: Direct evidence for intermolecular DNA deletion in V-D-J joining. Cell 49: 477-485.

Reth, M., P. Gehrmann, E. Petrac, and P. Wiese. 1986. A novel $\mathrm{V}_{\mathrm{H}}$-to-DJ $\mathrm{H}_{\mathrm{H}}$ mechanism in heavy-chain-negative (null) pre-B cells results in heavy chain production. Nature 322: $840-$ 842.

Rosenfeld, P.J. and T.J. Kelly. 1986. Purification of nuclear factor I by DNA recognition site affinity chromatography. $J$. Biol. Chem. 261: 1398-1408.

Saenger, W. 1984. Principles of nucleic acid structure, SpringerVerlag, New York, New York.

Sakano, H., K. Huppi, G. Heinrich, and S. Tonegawa. 1979. Sequences at the somatic recombination sites of immunoglobulin light-chain genes. Nature 280: 288-294.

Sakano, H., R. Maki, Y. Kurosawa, W. Roeder, and S. Tonegawa. 1980. Two types of somatic recombination are necessary for the generation of a complete immunoglobulin heavy chain gene. Nature 286: 676-683.

Sanger, F., S. Nicklen, A.R. Coulson. 1977. DNA sequencing with chain-terminating inhibitors. Proc. Natl. Acad. Sci. 74: $5463-5467$.

Siegel, L.M. and K.J. Monty. 1966. Determination of molecular weights and frictional ratios of proteins in impure systems by use of gel filtration and density gradient centrifugation. Application to crude preparations of sulfites and hydroxylamine reductases. Biochim. Biophys. Acta 112: 346-362.

Tonegawa, S. 1983. Somatic generation of antibody diversity. Nature 302: 575-581.

Tonegawa, S., A.M. Maxam, R. Tizard, O. Bernard, and W. Gilbert. 1978. Sequence of a mouse germ-line gene for a variable region of an immunoglobulin light chain. Proc. Natl. Acad. Sci. 75: 1485-1489.

Yancopoulos, G.D., S.V. Desiderio, M. Paskind, J.F. Kearney, D. Baltimore, and F.W. Alt. 1984. Preferential utilization of the most $\mathrm{J}_{\mathrm{H}}$-proximal $\mathrm{V}_{\mathrm{H}}$ gene segments in pre- $\mathrm{B}$ cell lines. $\mathrm{Na}$ ture 311: 727-733.

Yancopoulos, G.D., K. Blackwell, H. Suh, L. Hood, and F.W. Alt. 1986. Introduced T-cell receptor variable region gene segments recombine in pre-B cells: Evidence that B- and Tcells use a common recombinase. Cell 44: 251-259. 


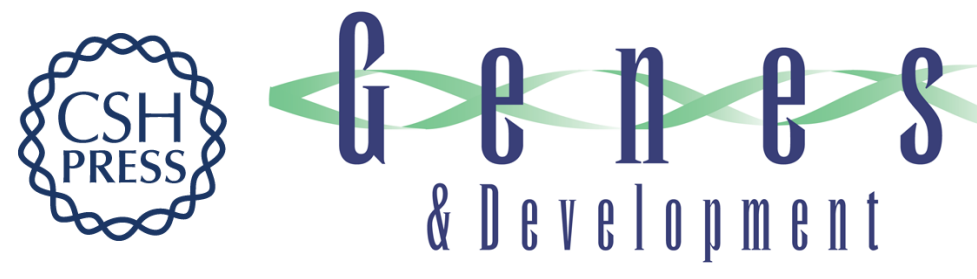

\section{NBP, a protein that specifically binds an enhancer of immunoglobulin gene rearrangement: purification and characterization.}

M Li, E Morzycka-Wroblewska and S V Desiderio

Genes Dev. 1989, 3:

Access the most recent version at doi:10.1101/gad.3.11.1801

References This article cites 42 articles, 15 of which can be accessed free at:

http://genesdev.cshlp.org/content/3/11/1801.full.html\#ref-list-1

License

Email Alerting

Service

Receive free email alerts when new articles cite this article - sign up in the box at the top right corner of the article or click here.

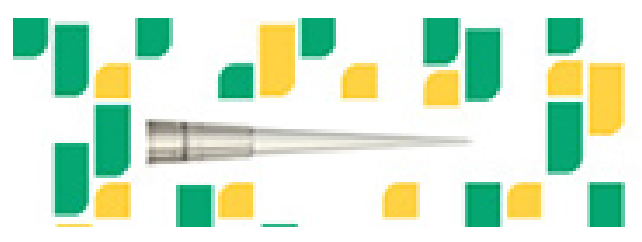

Focused on your science. 